\title{
حجية التوقيع الإلكترونى فى الإثبات ( دراسة فى التشريع العمانى )
}

\author{
shel \\ د. أحمد عبد الكريم موسى الصرايره \\ أستاذ مساعد القانون المدنى \\ رئيس قسم الحقوق - جامعتّظفار
}




\section{هقدمة}

الكتابـة لاتعتبر دليلا" كـاملا" في الإثبـات إلا إذا كانـت موقعـة ، فـالتوقيع هو عنصر من عناصر الـليل الكتابي المعد أصـلا " للإثبـات وهو الشرط الوحيد لصحة الورقة العرفية المعدة للإثبات(') ول ولهه وظيفة تتمثل في تحديد هويـة الموّقع والتعبير عن إرادته باعتبار أنا لتوقيع يعبر عن إرادة صساحبه، وللذلك فأنسه يجب أن يصدر من شخص كامل الأهلية(2) .ودون التوقيع يفقد الدليل الكتابي حجيته، فالتوقيع هو الذي ينسب الورقة إلى من وقعها حنى ولو كاتت مكتوبة بخط غيره ـ. اوق كان التوقيع بلاية يتم عن طريق الختم، ثم أصبح عن طريق الإمضاء بخط اليد، ثم توسـع ليشمل بصمة الإصبع لما لها من قدرة على تحديد هوية الموقع نظرًا لمـا أثثته العلم من قدرة بصمة الإصبع على تحقيق تلكك الوظائف، وعدم إمكان التشابه بين البصمات حتى عند الإنسان نفسه. لقد تظورت وسـائل الاتصال وظهر الحاسيوب الذي دخل مختلف نواحي الحياة المختلفة ـ وبعد أن أمكن ربطه بالهاتف أحدثت شبكة الإنترنت ثورة هائلة في مجالات الحياة المختلفة، وظهر مايسمى بالتجارة الإكترونيـة التي كانت بحاجـة إلى تواقيع تتلاعم مع طبيعتها، فظهر مـاعرف بـالتوقيع الإكترونـي .ولم يقتصر هذا التوقيع على شكل واحد، وإنما اتخذ عدة أشكال بدعًا بالتوقيع عن طريق الرقم السري وانتهى الآن بالتوقيع الرقمي الذي أخذ حيزًا واسعًا في مجال المعاملات الإكترونية ونـال الاعتراف

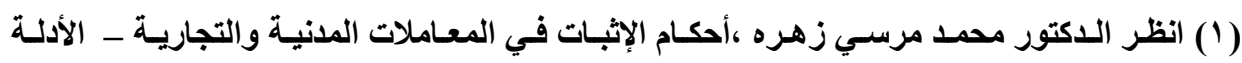

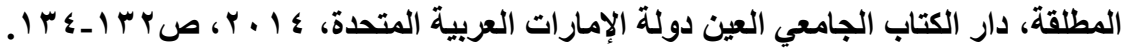

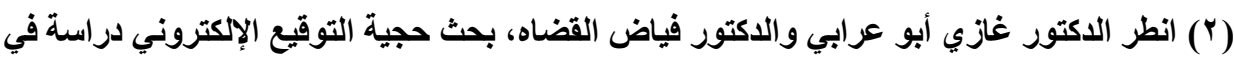

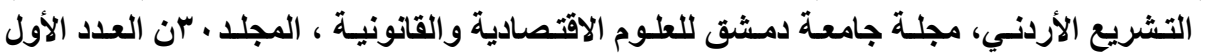


القانوني به. وتأتي هذه الاراسة بعد ازدهار التجارة الإكترونية على الصعيد الدولي، وبعد انضمام سلطنة عمـان إلى منظمـة التجارة العالمية وتوقيعها للعديد من اتفاقـات التجارة الحرة،حيث برزت الحاجة في التشريع العماني إلى إزالة العوائق القانونية التي تعيـق تقــدم التجـارة الإكترونيـة وتطور هـا مـن خـلال تشـريع متخـصص للمعـاملات الإكترونيـة، وفعـلا صسـر قـانون المعـاملات الإكترونيـة بموجب المرسـوم السلطاني

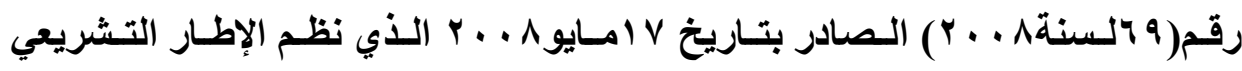
للتعـاملات الإكترونيـة، ويعتـرف بكـل مسن السجلات الإكترونيـة ورســائل البياتـات الإكترونية والتواقيع الإكترونية، وذلك من حيث صدلاحيته الإنشاء التزامـات قانونية، وســـح بإنشـاء جهـات التوثيق والتصديق والتواقيـع الإكترونيـة، مسن حيث قبولهـا كوسائل إثبات أمسام المحاكم وإعطاؤها الحجية في الإثبات إلى جانب الوسـائل التقليليـة المبنية على السندات والثهادة وغيرها ـ ب وبنـاء" على ذلك سـوف نقسم هذا البحث السى مبحثين يتــاول الأول تحديــ حجيتهـ التوقيـع الإكترونسي في قـانون الإثبـات في المعاملات المدنية والتجارية ويتناول المبحث الثاني حجية التوقيع الإكتروني في قانون المعـاملات الإكترونيـة،من خـلال تحديــ الحسالات التـي يقبـل فيهـا التوقيع الإكترونـي والحالات التي لايجيز فيها القانون التوقيع إلكترونيَا وبيـان الشروط القانونية اللازمـة لألك. 


\section{المبحث الأول \\ حمية التوقيع الإلكتروني في قانون الإثبات \\ في المعاملات المدنية والتجارية}

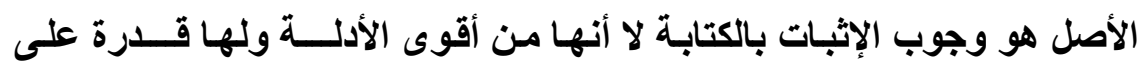
توثيق المعامــــلات بين الأطـراف، إلا أن المشرع العماني خرج في قانون الإثبـات في

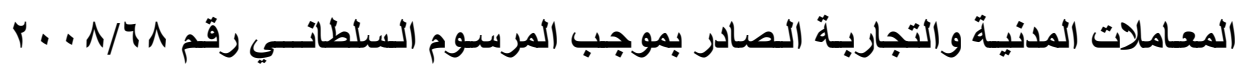
عن ذلك في العديد من الحالات منها، إثبات الأعمال التجارية إذا أجاز الإثبات فيها مهما بلغت قيمتها حيث نصت المادة رقم (1 ) منه على أنه " فيغير المواد التجارية إذا كان التصرف القانوني تزيد قيمته على ألف ريال أو كان غير محدد القيمة، فلا تجوز شهادة الثهود في إثبات وجوده أو انقضائه مالم يوجد اتفاق أو نص يقضي بغير ذلك . ......" هوإذا كان المشرع قد ألزم في المعاملات التي تزيد على قيمتها على ألف ريـال الإثبات بطرق معينة حيث لم يجز الإثبات بالكتابـة إلا أنـه استثثى من ذلك عدة حالات،أهمها: حالة وجود مبأ ثبوت بالكتابـة ووجود مـانع من الحصول على الدليل الكتابي، وحالة فقدانه ذا الدليل أو ضياعه، وهذا من نصت عليه المـاده (ب ؛ ) من قانون الإثبات في هي المعاملات المدنية والتجارية بقولها :" يجوز الإثبات بشهادة الشهود فيمـا كـان يجب الشب إثباته بالكتابة في الاحوال الآتية :

أـ إذا وجــ مبـدأ ثبـوت بالكتابـة، ويعتبـر مبــأ ثبـوت بالكتابـة كل كتابـة تـصدر مسن الخصم ويكون مسن شــأنها أن تجعل وجـود التصرف المـدعى بـه قريـب

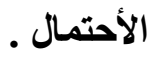


بـ إذا وجد مانع مادي أو أدبي يحول دون الحصول على دليل كتابي . ج- إذا فقد الدائن سنده الكتابي بسبب أجنبي لايلله فيه . دـ إذا رأت المحكمة لأسباب مقتعه الإثبات بشهادة الثهود ". بناء على ذلك، فإنتا سوف نتناول ذلك في المطالب الثلاث التالية: - المالب الأول: مدى قبول التوقيع الإكتروني في المعاملات التجاريـة والالتزامـات المدنية التي تقل قيمتها عن ألف ريال.

- المطلب الثاني: مدى قبول التوقيع الإكتروني إذا وجد مـاتع من الحصول على

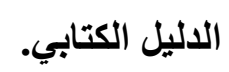
- المطلب الثالث: مدى قبول التوقيع الإكتروني في حالة فقدان السند الكتابي.

\section{المطاب الأول}

\section{هدى قبول التوقيع الإلكتزوني في المعاهلات التجارية والالتراهات المدنية}

\section{التي تقل عن ألف ريال}

القاعدة العامـه ان العقود التجاريـة يجوز إثباتها بكافة طرق الإثبات باستثناء

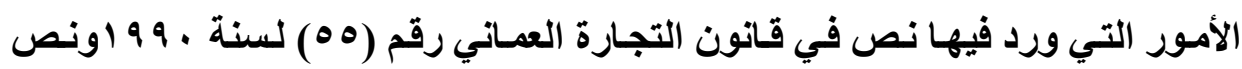

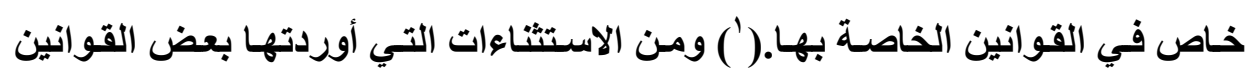


الخاصـة عقود بيع و إنشاء حقوق عينيـة على السفن (م V I من القـانون البحري

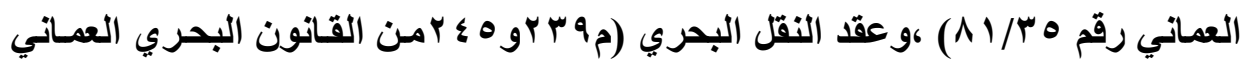

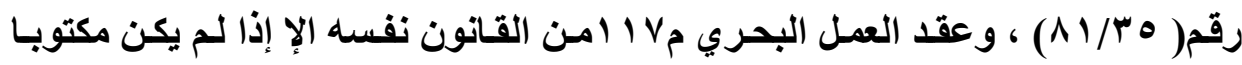
أجاز إثباته بكافة الطرق )، وعقد التأمين على السفن والبضائع (مب آT من القانون

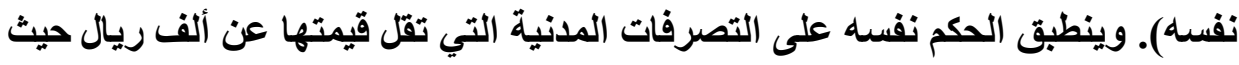

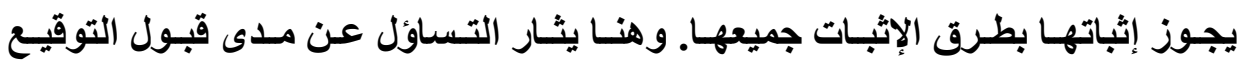
الإكتروني في هذه التصرفات والمعاملات التجارية؟ وهذا ماسوف نحاول الإجابة عنه بشيء من التفصيل على النحو الآتي:

\section{الفرع الأول \\ هدى قبول التوقيسـع الإلكتزوني في المعاملات التجارية}

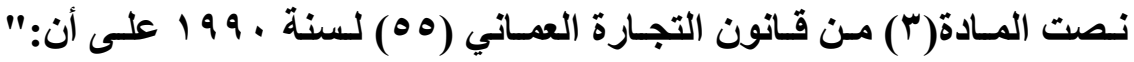

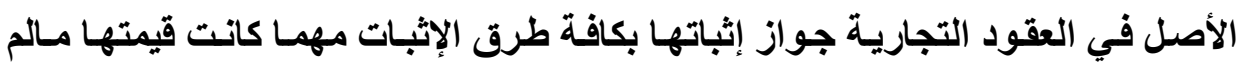
تنص مواد هذا القانون على خلاف ذلك." ومن خلال استقراء هذا النص نجدا أنه يجوز

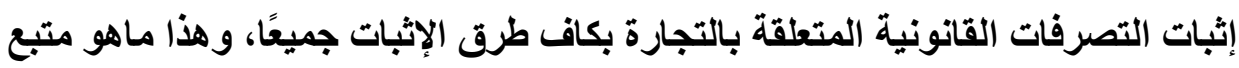

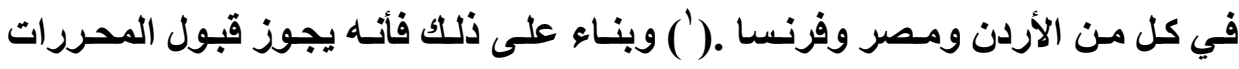

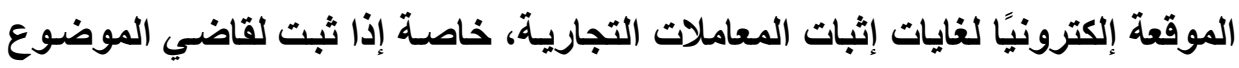

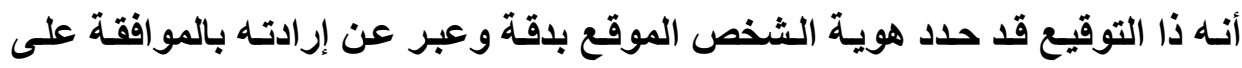

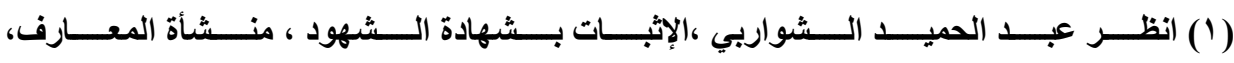

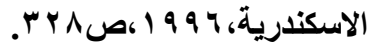

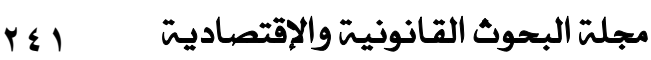


مضمون السند، وعدم منازعة الأطر اف في صحته('). نخلص مما تقدم، إلى أنسه، مـادام أن المشرع العماني قد اعتمد مبدأ الإثبات الحرفي المعاملات التجارية فأنه يجوز إثباتها من خلال المحررات الموقعة إلكترونيًا طالما أن التواقيع الإكترونية قد صدرت بصورة تضمن موثوقيتهـا، فعلى القضاء طالمـا أن القـانون فتح المجـال أمسام استخدام جميع الوسائل لإثبات المعاملات التجارية، أن لايعيق قبول مثل هذه التواقيع خاصة؛ لا أنه في حـال لـم يأخــ القضاء بـالتواقيع الإكترونيـة، فـان ذلـك يهـدد الثقـة فـي التعامـل بهـا ويتعارض مع الأمان الذي حرصت التشريعات المعاصرة على توفيره للمستهلكين(ب). وهذا موقف محكمة التمييز الأردنية التي قبلت ألفـاكس لإثبات المعـاملات التجاريـة في قرار لها جاء فيه :”إن إنشـاء وإصدار المخاطبات بواسطة ألفـاكس التي شـاع التعامـل بها في العصر الحديث وعلى الرغم من أن هذه المحررات ليست من الأوراق الرسمية بـالمعنى الوارد في قـانون البينـات إلا أنها محررات أصبح استعماله او التخاطب بهـا والتعاقد بها شـائعا"، وإن عدم اكتسابها الصفة الرسمية لايحتم استبعادها من عداد البينـات المنتجـة في الإثبات، وكـان على محكمـة الاستئنـاف ومحكمـة البدايـة السماح للمميزه تقديم البينة الشخصية لبيان وتحديد كيفية صدورها، ومن الذي أصدرها، ومـا الغاية من إصدارها، وكيفية التخاطب بها أو التعاقد بواسطتها، ويكون استبعادها من البينات بحجة أنها ليس محررات رسمية، لايقوم على أساس سليم من القانون ولاسيما أن القضية موضوع البحث تتعلق بمسائل تجارية يجوز إثباتها بالبينة الثخصية فيمـا

(1) انظر الــكتور حسام لطفي ، الاطـار القـانوني للتجــــة الإكترونيـة ، جامعـة الـدول العربيـة ،

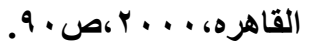
(r) انظر حسن عبد الباسط جميعي ، إثبات التصرفات القانونية التي يتم إبرامها عن طريق الإنترنت،

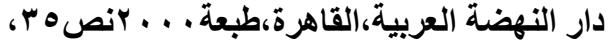


يخالف أو يناقض ما اشتمل عليه دليل كتابي(1)”.وهذا يؤيد وجهة نظرنا،وما ذهب اليه

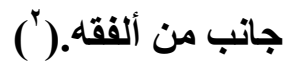

نخلص ممـا تقدم، أن التوقيع الإكترونسي مقبـول في إثبـات المعـاملات التجاريـة مهمـا بلغت قيمتها على أسـاس أجـازة القـاتون لمثل هذا الأمر أيـ حريـة الإثباتـ في مثل الإنل هذه المعـاملات. فالمشرع العــاني لـم يتــاول حجيـة التوقيع الإكترونـي صـراحة في قـانون الإثبـات في المعـاملات المدنيـة والتجاريـة الـصادر بالمرسـوم السلطاني رقـم

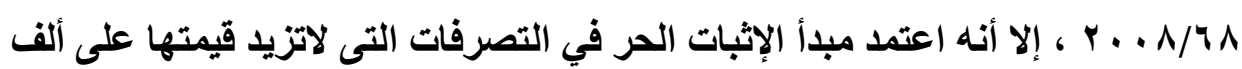
ريال ، وحالة وجود مبدأ ثبوت بالكتابة فأنه ليس ما يمنـع أن يكون للتوقيع الإكتروني حجية في الإثبات لم يثبت من نسب إليها أنه لـ يقم بذلك. فليس من العدل رفض مثل هـذه الوسـائل فـي المسـائل التجاريـة الأخـرى غيـر تلــك المتعلقـة بـالبنوك والأوراق

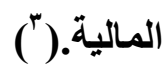

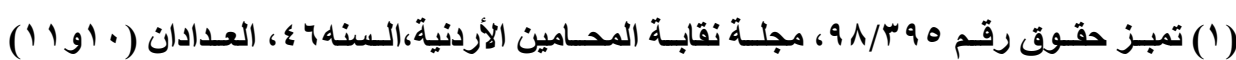

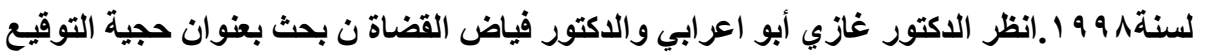

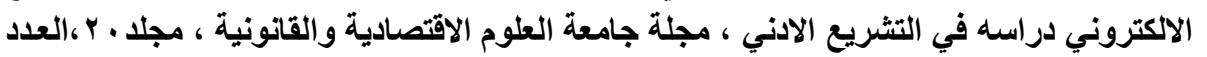

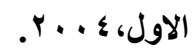

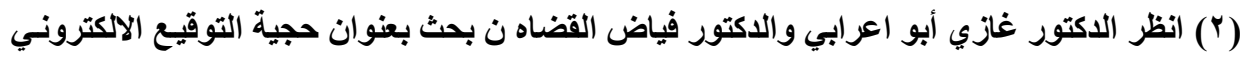

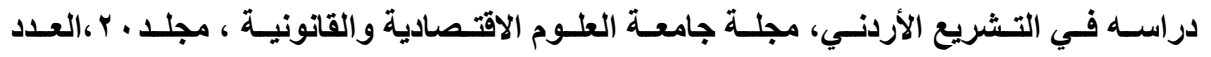

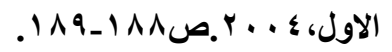

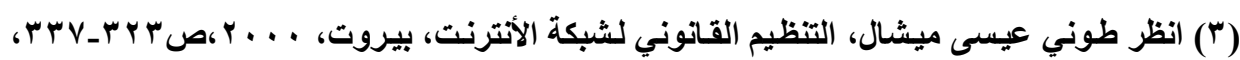

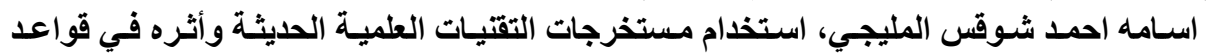

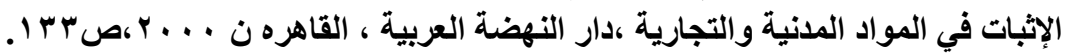




\section{الفزرع الثاني \\ هـدى قبـول التوقيـــع الإلكتزونـي في الالترزاهـات \\ المدنية التي تقل عن ألف ريال}

أجاز المشرع العماني إثبات التصرفات القانونية التي لاتزيد قيمتها على ألف

ريـال بجميع طرق الإثبات. وهذا مانصت عليـه المـادة (1 \& ) مسن قـانون الإثبات في

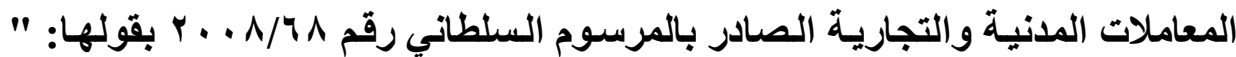
في غير المواد التجارية إذا كان التصرف القانوني تزيـ قيمته على ألف ريـال أو كـان غير محدد القيمة، فلا تجوز شـهادة الشهود في إثبات وجوده أو انقضائه مسالم يوجد اتفاق أو نص يقضي بغير ذلك . ......" ". وتفسير ذلك أن الالتزامات التي تقل قيمتها عن ألف ريال وحتى لاتطول مدة المنازعات، فإن المشرع لم يشترط الكتابـة لإثباتها، لا أنهـا التزامـات إذا تقيمـة ماديـة قليلـة. وحتى لايـتم اشـغال القضاء بـأمور ليست ذات أهمية، (') لذلك يجوز إثباتها بالشهادة ومن بـاب أولى بجميع وسـائل الإثبات الأخرى ومنها المحررات الموقعة إلكترونيا حيث ان المشرع العماني أجاز في المـادة رقم(1

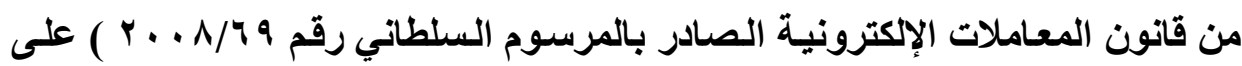
أنـهـ : " 1 ـ عنــ تطبيق قواعد الإثبـات في أيـة إجـراعات قانونيـة لايحول دون قبـول الرسالة الإكترونية أن تكون قد جاءت في غير شكلها الأصلي، إذا كانت الرسالة أفضل

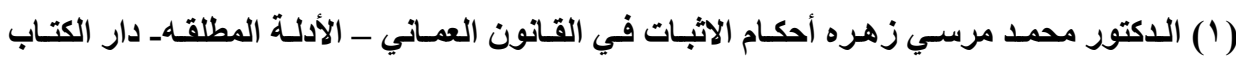

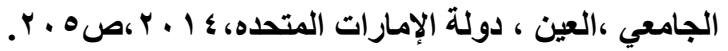


دليل يتوقع بلرجة مقبولة أن يحصل عليه الثخص الذي يقدمه، وتكون لهذه الرسـالة حجية في الإثبات مع مراعاة الآتي :

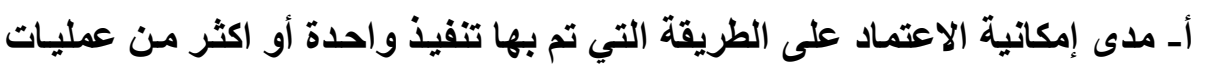
التنفيذ أو الإنثاء أو المعالجة أو التخزين أو التقديم أو الإرسال.

ب ـ مـدى إمكانيـة الاعتمـاد على الطريقـة التـي تــت بهـا المحافظة على سـلامة المعلومات . - المات

ج - مدى إمكانية الاعتماد على مصدر المعلومات إذا كان معروفا. دـ مدى إمكانية

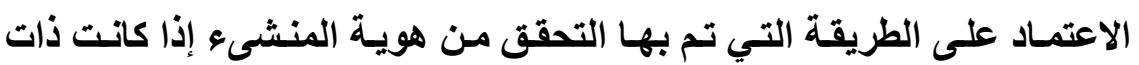

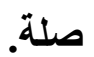

ه ـ أي عامل أخر ذو صلة .مالم يثبت العكس، يفترض أن التوقيع الاكتروني محمي

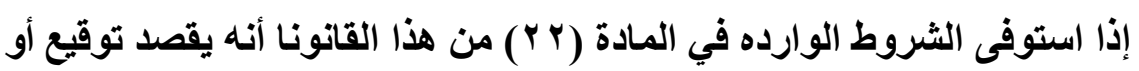

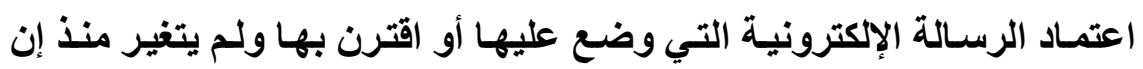

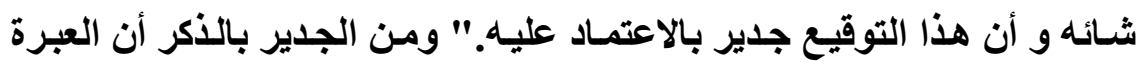

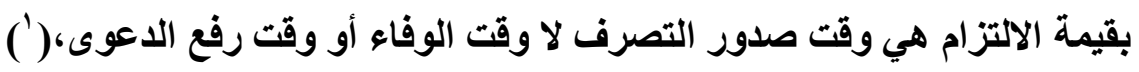

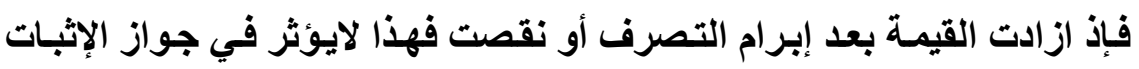

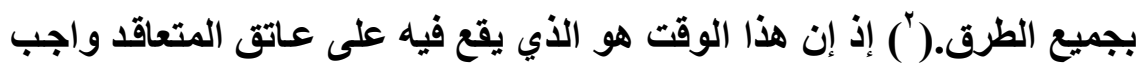

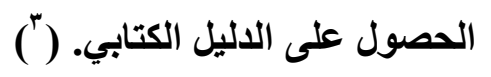

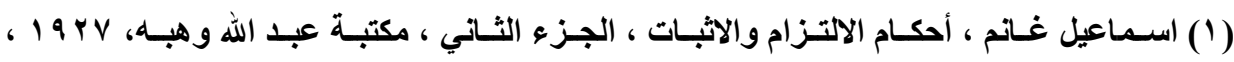
ص ص

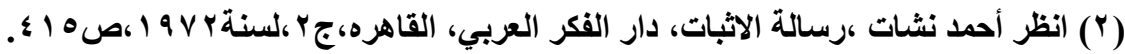

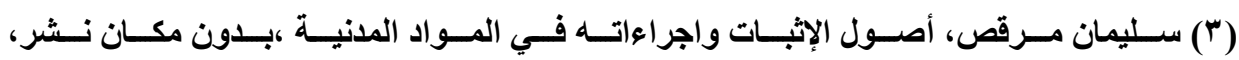

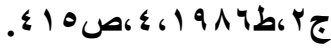


وطالما أن القانون أجاز ثبات الالتزامات التي تقل قيمتها عن ألف ريـال عماني بالثهادة، فإن ذلك يعني من باب أولى أجازة إثباتها بـالطرق الأخرى ومنها المحررات الموقعة إلكترونيًا إذ إن لها قوة أكبر من الشهادة في الإثبات رغم ورودهـا في شكل إلكترونسي(') ـ وهذا يحقق فائدة عملية وهي إثبات المعـاملات التي تنتم عبر شـبكة

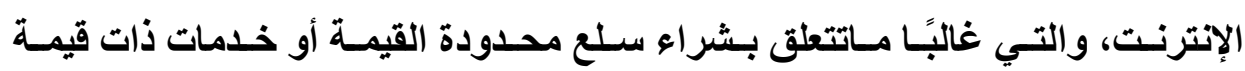
محدودة، وهذا من شأنه تسهيل التعاقد عن طريق الإنترنت بشكل كبير. وأخيرًا لابد من الإشـارة إلى أن نطاق قبول التوقيع الإكتروني في مثنل هذه الالتزامـات والتي لاتزيـ قيمتهـا على ألف ريسال محصور في حدود النصوص القانونيـة، ولايجوز استخدامه لإثبات ماهو ثابت كتابة سواء كان في سند رسمي أم عادي أو إثبات جزء بـاق من حق

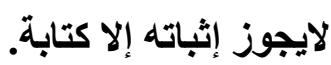

\section{المطاب الثاني}

\section{هدى قبول التوقيع الإلكتزوني إذا وجد مانع}

\section{هن الهصول على الدليل الكتابي}

إذا وجد مبدأ الثبوت بالكتابة(r)، فإن المشرع العماني جعل لمبدأ الثبوت بالكتابة

قوة الإثبات متى ماكان مبدأ الثبوت بالكتابة معززا" بالبينة والقرائن دليلا كتابيـا كاملا في كل مايجب إثباته بالكتابة. وبالتـالي فانـه لايستلزم إثبات الالتزام بالكتابـة حتى ولو

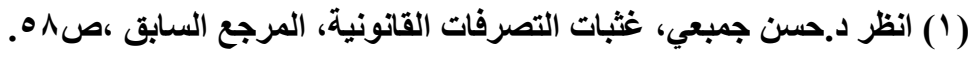

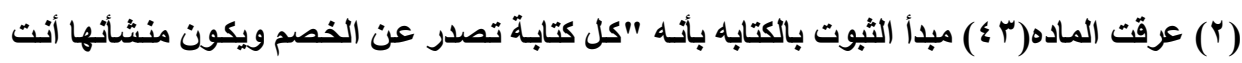
جعل وجود المدعى به قريبا لاحتمال". 
كانت المعاملة مدنية وتزيد قيمتها على ألف ريـال عمـاني؛ إذ يجوز إكمال هذا المبدأ بالثهادة ويأي طريق من طرق الإثبات الأخرى ومنها التوقيع الإكتروني. كذلك يقال الشيء نفسه إذا وجد مـانع مـادي أو أدبي من الحصول على دليل كتابي. إذا يقتضي

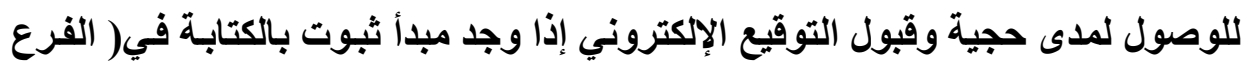

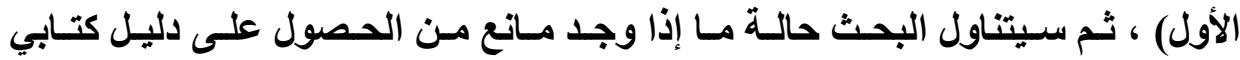

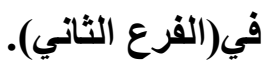

\section{الفرع الأول \\ قبول التوقيع الإلكتزوني إذا وجد هبدأ ثبوت بالكتابة}

استثنى المشرع العماني عدة حالات أجاز فيها الإثبات بالشهادة وبجميع طرق

الإثبات الأخرى. -على سبيل الاستثاء ـ بالرغم من أنه قد تطلب إثبات الأعمال المدنية التي تزيد قيمتها على ألف ريـال عمـاني بالكتابة، وهذه الحالات نصت عليها المسادة (r \& ) من قانون الإثبات في المعاملات المدنية والتجارية منها مبدأ الثبوت بالكتابة. ويقصدبه " كل كتابة تصدر عن الخصم ويكون من شأنها أن تجعل وجود المدعى بـه قريبا لاحتمال ."(')، فيعدو جود هذا المبدأ في محاولة إثبات حق مسا، فإن الإثبات يتت إتمامة بالثهادة فتصبح الثهادة دليلا "مكملا" أو متممًا " إذ هي تقتصر على تعزيز الدليل الناقص المستمد من الكتابة، ويصبحا معًا دليلا كاملا على دعوى المدعي(").

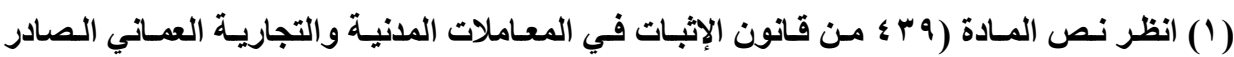

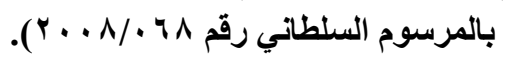

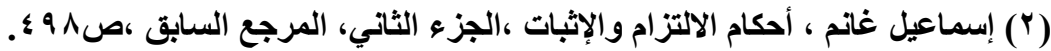


وحتى يتو افر مبدأ الثبوت بالكتابـة يشترط أن يحتوي السند كتابـة، وأن يكون السند صادر|" من الخصم الذي يحتج عليه بها كأن يكتب شخص مـا تعهدًا بخط يـا هو لكنـه لايوقعه. فالكتابة بخط اليد دون توقيع تجعل من الحق المدعى به قريب الاحتمال، ولكنـه ليس دليلا كافيًا فلابد من إتمامه بالثهادة فإن شهـ شهود على أن إرادة كاتب التعهد قد انصرفت إلى الالتزام به وأصبح الحق ثابتا، وأن مبدأ الثبوت بالكتابة موجود وتتوافر فيه الثروط، اللازمة لوجود مبدأ الثبوت بالكتابة، وبالتـالي فأنسه يفتح المجال للقاضي أن يتحقى ان الحق المدعى به ثابتا ' أن يكمل هذا الدليل عن طريق السماح للمدعي بالاستدلال بشهادة الشهود وغيرها من طرق الإثبات الأخرى، ومنها التوقيع الإكتروني في المحررات الإكترونية، للدعم الورقة الصادرة من الخصم ويرجيع في تقدير هذه المسألة الموضوعية للقاضي الموضوع يستقل بها دون رقابة عليه من المحكمة العليـا ووعليه فإن التوقيع الإكتروني يحقق الثقة والأمان في التعامل في مختلف صوره، ومـع وجود مبدأ الثبوت بالكتابة، فإن هذه الثقة قد تفوق الثهادة التي تعد حجة غير ملزمـة وللقاضي سلطة تقديريـة واسعة في تقدير الإثبات بالشهادة للتأكد من صدق الشاهد وعدم تزويره للحقيقة. فالتوقيع الإكتروني يتعذر تزويره الا إذا حصل تقصير من جاتب الموقع في المحافظة على توقيعه. 


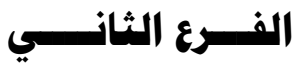 \\ هدى قبول التوقيع الإلكتزوني إذا وجد مانع \\ هن المصول على الدليل الكتابي}

أجـاز المشرع العمـاني الإثبات في مايجب إثباتـه بالكتابـة، بكافة طرق الإثبات

في حالة وجود مـانع- وقت إبرام التصرف - من الحصول على الدليل الكتابي. ففي هذه الحالـة يجوز للشخص الذي تعذر عليه الحصول على دليل كتـابي لقيـام المـاتع المادي أو الأدبي من إثبات حقه عن طريق الثهادة وغيرها من طرق الإثبات الأخرى، حتى ولو كان تقيمة المدعى به تزيد على ألف ريـال عمـاني أو كـان غير محدد القيمة.، كما يجوز الإثبات بهذه الطرق في ما يخالف أو يجاوز ما اشتمل عليه دليل كتابي. وهذا مـا تؤكده في المـاده (بـ ) مـن قانون الإثبـات في المعـاملات المدنيـة والتجاريـة التي تنص على مايسأتي: يجوز الإثبات بشهادة الشهود فيمـا كـان يحب إثباتـه بالكتابـة في

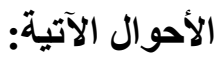

ب - إذا وجد مانع مادي أو أدبي يحول دون الحصول على دليل كتابي. " .........

يتضـح مـن خـلال هذا النص أن المسشرع العمــي يجيز الإثبـات بالشهادة إذا توافر مانع مايمنع من الحصول على الاليل الكتابي. وهذا المـانع إمـا أن يكون ماديًا أو أدبيًا.

فالشهادة وغيرهـا مـن طرق الإثبـات لاتكمـل الكتابـة، وإنمـا تحل محل الـلـليل الكتابي ذاتهه إذا استحال الحصول عليه، إذ لاتكليف بمستحيل، إلا في العقود الشكلية 
التي تتطلب الكتابة كثرط للانعقاد، فانعدام الكتابة هنا يعني انعام التصرف في ذاتهاه(')

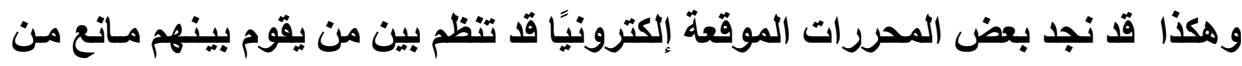

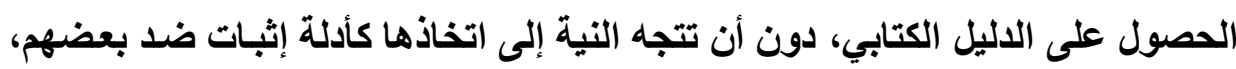

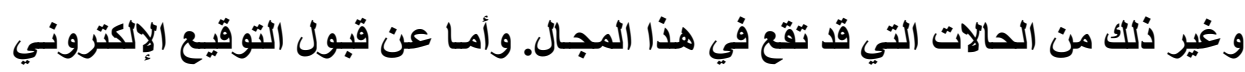

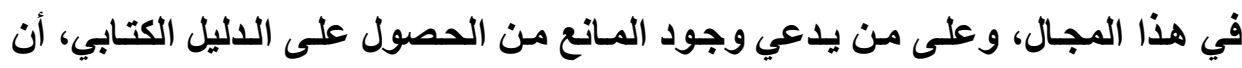

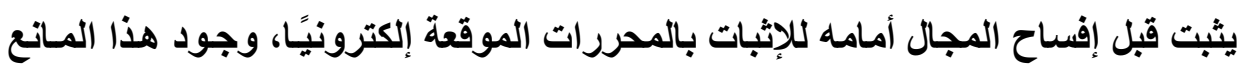

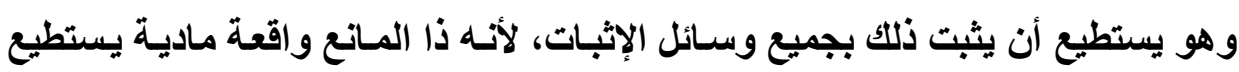

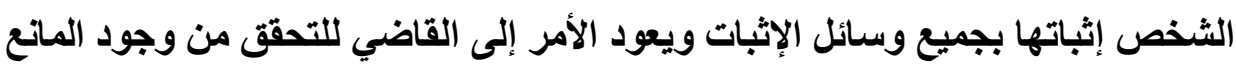

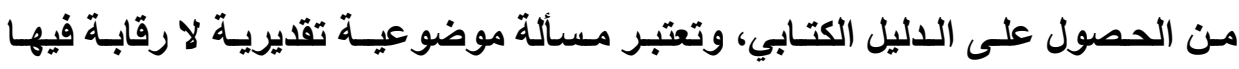

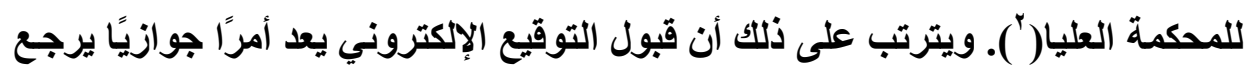

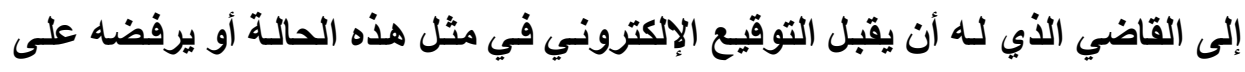

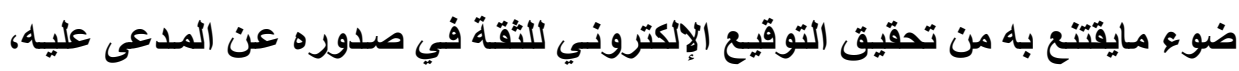

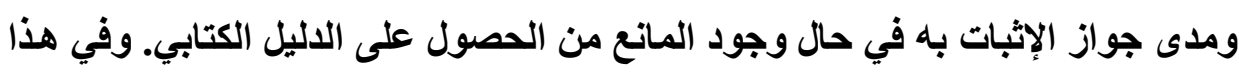

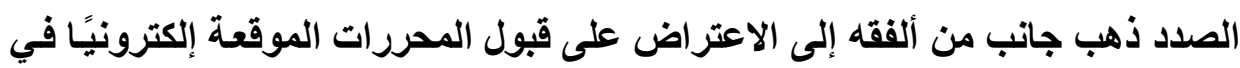

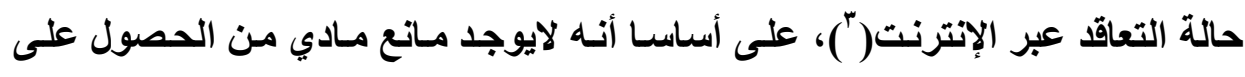

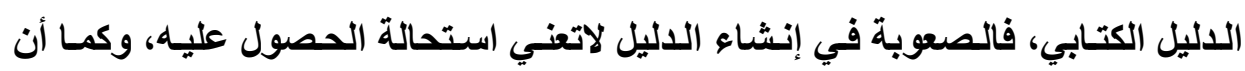

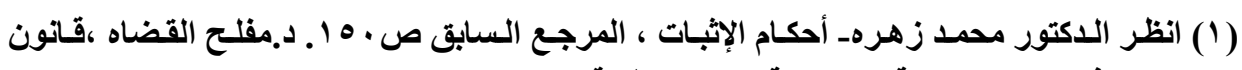

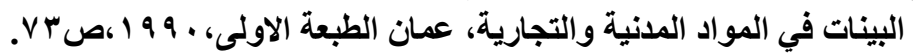

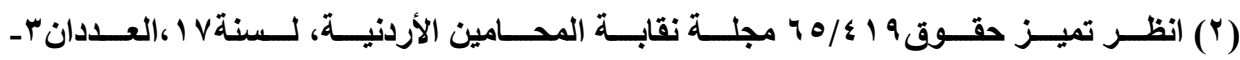

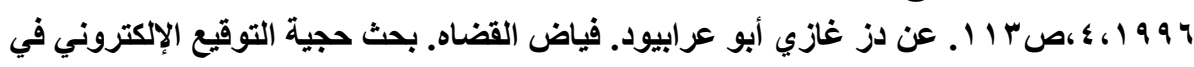

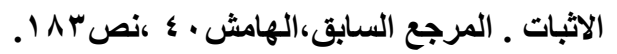

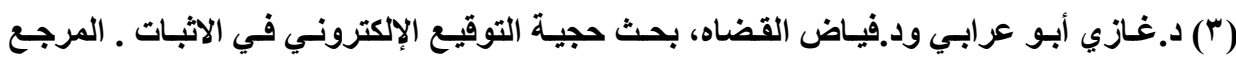

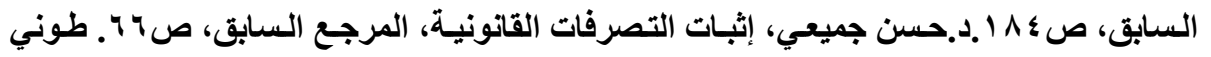

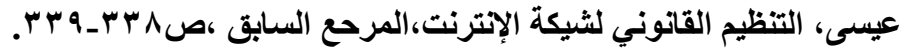


التعاقد عبر الإنترنت ليس أمرًا ضروريا للتعاقد، إذ يستطيع الشخص الاستغناء عنه، أهـاء وكذلك ليس هنـاك مـانع أدبي يرجيع إلى اعتبـارات وظروف نفسية بين المتعاقدين، وكذلك إلى عدم قيام عرف يمنـع مـن الحصول على الدليل الكتابي عند التعاقد عبر

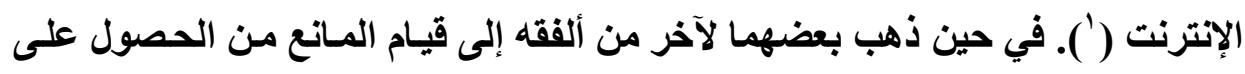

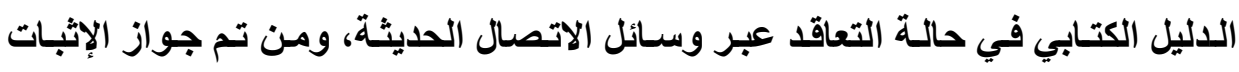
بالمحررات الإكترونية، على أساس الفهم الواسـع لفكرة المـانع المسادي، ومـن ثم فبان وسائل التقيات الحايثة يمكن أن تلخل ضمن الإستثناء الذي نصت عليه المـاده (ب ع)

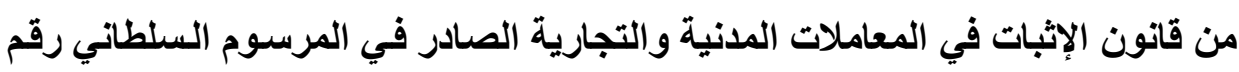

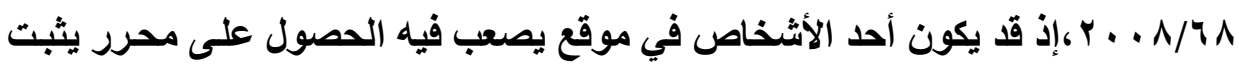

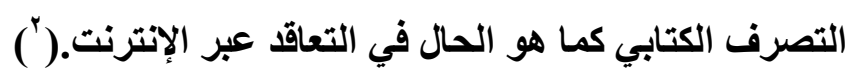

نخلص ممـا تقدم إلى أن التعاقد عبر الإنترنت يجعل مـن الاستحالة أن يحصل

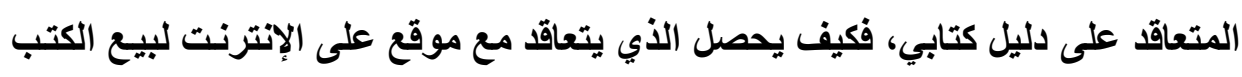

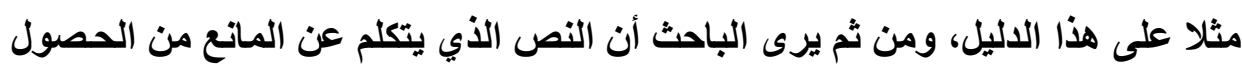

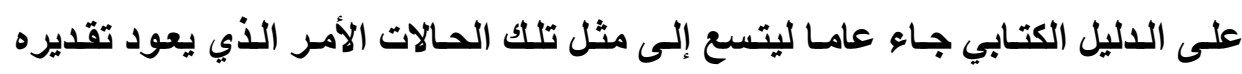
للقاضي، وبنـاء عليه يكفي في حالة التعاقد عبر الإنترنت استتساخ الصفحة المثبتة للعقد الذي تـم بـين الطرفين وتقديمسه للإثبـات على أسـاس وجـود المـانع المـادي مـن

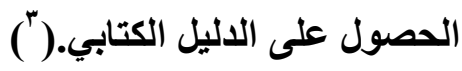

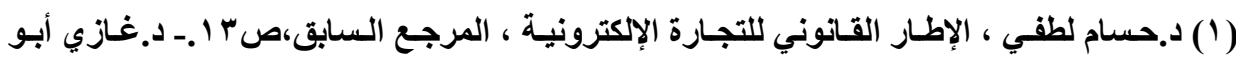

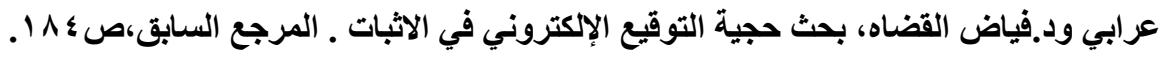

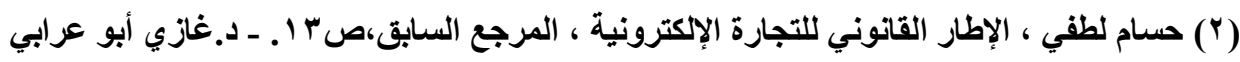

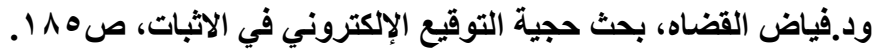

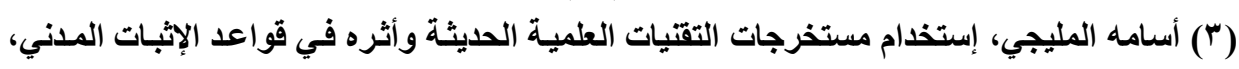

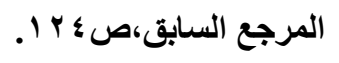




\section{الامطاب الثالث}

هدى قبول التوقيع الإلكتزوني في حالة فقدان السند الكتابي

نصت عليـه المـادة (ب ؛ ) مـن قانون الإثبات في المعـاملات المدنيـة والتجاريـة الصادر في المرسوم السلطاني رقم ^^/1 ـ . . r في فقرتها على أنه:

"يجوز الإثبات بثهادة الثهود فيما كان يجب إثباته بالكتابة في الأحوال الآتية: أ

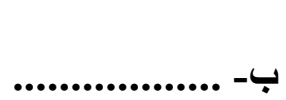

ج- إذا فقد الدائن سنده الكتابي بسبب أجنبي لايد له فيه.

من خلال هذا النص نجد أن المشرع العماني استثنى الحالة التي يفقد فيها السند الكتابي من لزوم الإثبات كتابة. فإذا كان لاى أحد المتعاقدين عند إنشاء التصرف سند مكتوب سواء كان رسميًا أو عرفيًا، لكنه فقده لسبب أجنبي لايد له فيه، كقوة قاهرة مثل حدوث حريق أو غزو أو فعل صادر من الخصم كأن ينتزع السند من الدائن بـالقوة أو الحيلة ويقوم بإتلافه، وقد يكون السبب الأجنبي بفعل الآخرين كسرقة السند دون أن ينسب إهمال المحافظة عليه إلى من يتمسك بهذا السند (') ويمكن إثبات هذه الأفعال بجميع طرق الإثبات لأنها وقائع مادية يجوز إثباتها بجميع طرق الإثبات. والسؤال الذي يثار هنا، هل يمكن قبول التوقيع الإكترونسي في مثل هذه الحالةٌ. إن مثل هذا الأمـر

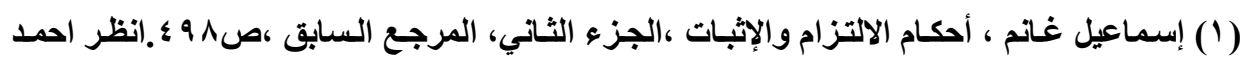

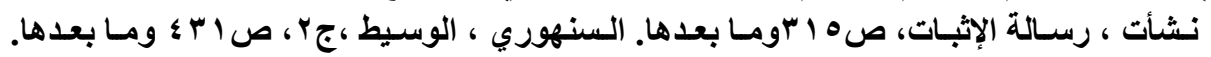

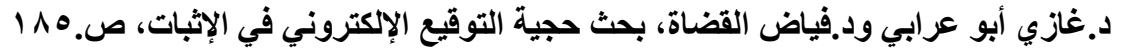


يمكن أن يقع، إذ قد يكون التصرف القانوني قد نظم بواسطة أسناد كتابية مستكملة جميع شرايطها القانونية، ويكون هذا التصرف قد نظم أيضًا بواسطة محررات موقعة إلكترونيًا، ففي حالة فقدان السند الكتابي لسبب لايد لصاحبه فيه،يمكن لـه استنادًا إلى نص الفقرة (ج) من المادة (ب ع) من قانون الإثبات في المعاملات المدنية والتجاريـة، الإثبات ومنها المحررات الموقعة إلكترونيًا، وهذه يختص بتقديرها قاضي الموضوع من الإني لأنها مسألة موضوعية، فالأمر يعود إلى تقدير هو ذلك حسبما يتبين لله من موثوقية التوقيع الإكترونـي ونسبته إلى صساحبه وقدرته على التعبير عن إرادته. يضاف إلى التى ماتقدم أن الإثبات بـالمحررات الموقعة إلكترونيًا ترد على السندات الرسمية كمـا ترد على السندات العرفية. وهذه السندات يمكن فقدا أنها، ويترتب على ذلك أن نص المـادة (ب ع) من قـانون الإثبات في المعـاملات المدنيـة والتجاريـة جـاء مطلقَا" لـم يميز بين السند الرسمي والسند العرفي. 


\section{المبحث الثانـي \\ حبية التوقيع الإلكتروني في قانون المعاهملات \\ الإلكتزونية العماني}

بالرجوع إلى قانون المعاملات الإكترونية العماني الصادر بالمرسوم السلطاني

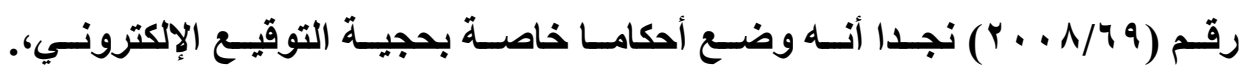

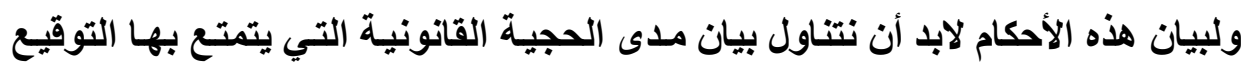

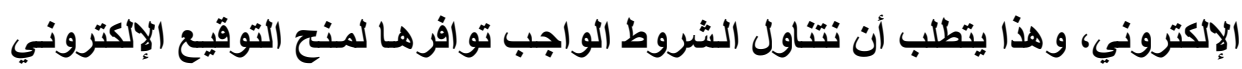

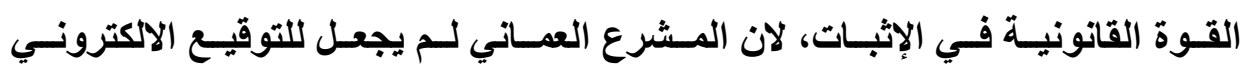

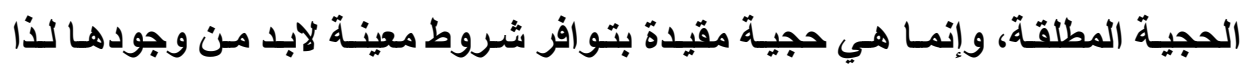

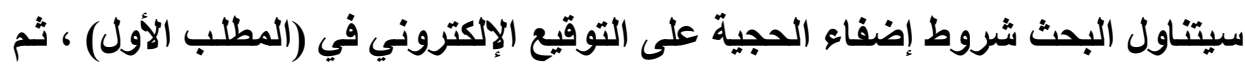

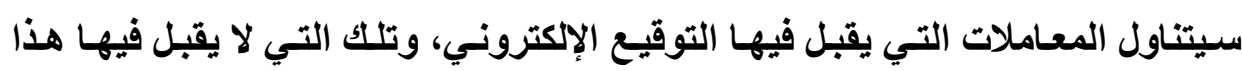

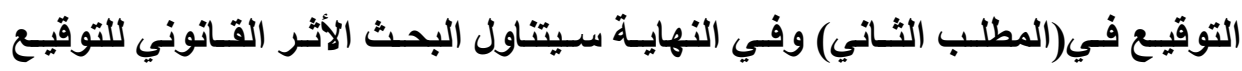

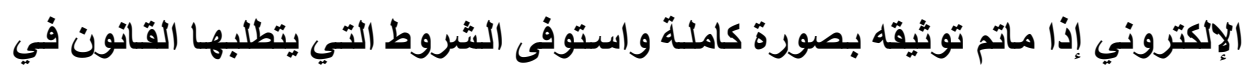

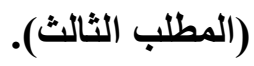

\section{المطاب الأول}

\section{شروط إضفاء العبية على التوقيع الإلكتزوني}

يمكن تقسيم هذه الشروط إلى قسمين: شروط موضوعية لابد أن تتوافر في

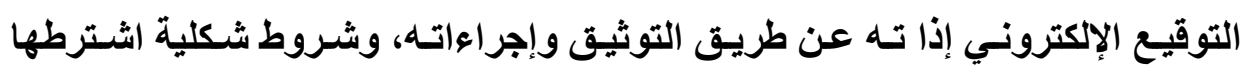
القانون في التوقيع الإكتروني حتى يستطيع القيام بوظيفته بتوثيق السجل الإلكتروني. وذلك في ألفرعين التالين : 


\section{الفرع الأول \\ الشروط الموضوعية الإلاوبة في التوقيع الإلكتزوني

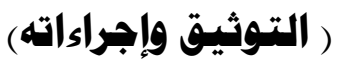

يتطلب القانون في التوقيع ذاتهه جملة من الشروط الموضوعية حتى يكون لـه الحجة القانونية الكاملة وهذه الثروط هي:

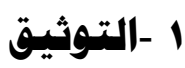

ويقصد به مجموعة من الإجراءات تهدف الى التحقى من أن المستثد الاككتروني قد صدر بشكل معتمد ومقبول تجاريًا أوتم باتفـق بين الأطراف بهدف التحقق من أن السند الاكترونيًَ و (التوقيع الإكتروني) لـم يتعرضـا إلى أيسة تعديل من تـاريخ التحقق منه وفقا" لإجراءات التوثيق. (م 1)من قانون المعاملات الإكترونية العماني. ولايكون

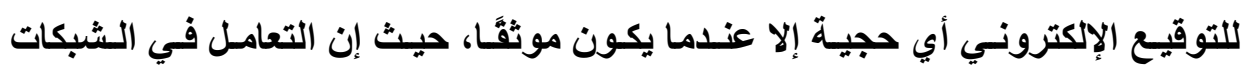

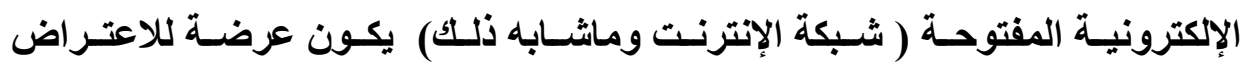
والتزويـر مسن قبـل القراصـنة المحترفين في اعتراض الأعمسال الإكترونيـة ولايمكن مواجهـة مثثل هـذه المخـاطر إلا مسن خـلال جهـة معتمـدة تعــل على توثيق التوقيع الإكترونـي حفاظـا على حقوق ومـصالح الأفراد والمؤسسسات التي تستخدم التوقيع الإلكتروني. وهذا مانصت عليه المادة (Y Y ) من قانون المعاملات الإلكترونية العمـاني التي تنص على انه " يعتبر التوقيع الإلكتروني محميا" وجديرا" بـأن يعتمد عليه إذا

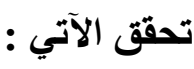

أ. كانت أداة إنشاء التوقيع في سياق استخدامها مقصورة على الموقع دون

$$
\text { غيره. }
$$


ب. كاتت أداة إنثاء التوقيع في وقت التوقيع، تحت سيطرة الموقع دون غيره ـ. ج. كان ممكناً كشف أي تغيير للتوقيع الإكتروني يحدث بعد وقت التوقيع . د. كان ممكناً كشف أي تغيير في المعلومات المرتبطة بالتوقيع يحدث بعد وقت

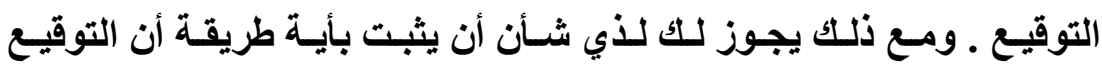
الإكتروني جدير بأن يعتمد عليه أو أنه ليس كذللك.

إلا أنتـا نعتقــ أن هذا التشدد يــف مـن نطـاق استخدام التوقيع الإكترونسي

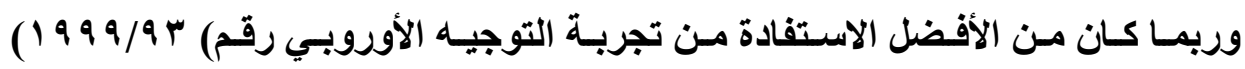
المتعلقة بـالتوقيع الإلكترونس، وهذا التوجيـه يعرف نـوعين من التواقيع الإلكترونيـة، الأول: التوقيع الإكترونـي المتقدم (المعزر) حيث يكون لـه حجية كاملـة في الإثبـات

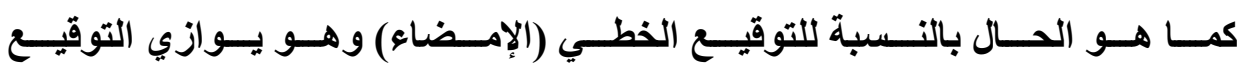
الإكترونـي الموثُق في القـانون العمـاني ـ والثـاني: التوقيع الإكترونـي غير الموثثق ويعود تقديره إلى قاضي الموضوع وفقَا لظروف استخدام التوقيع من حيث القبول و

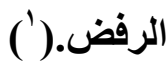

\section{r - تهقيق الصفات القانونية لالتوقيع.}

إذا كاتت الإجراءات المتبعة في توثيق التوقيع الإكترونيه بإجراعات معتمدة أو

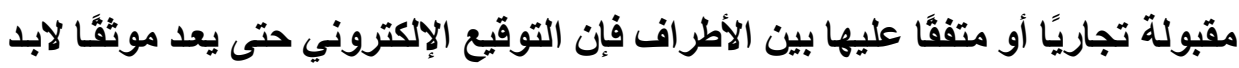
أن يحقق الصفات الآتية: 


\section{أ- أن يكون التوقيع متهميرزًا بشكل يظهر ارتباطه بالشخص صاحب العلاقة:}

والهدف من ذلك هو ضمان عدم قيام شخص آخر بإنشاء التوقيع الإكتروني نفسه بحيث يكون هذا التوقيع منفردًا ومرتبطَا بالشخص صاحب العلاقة ارتباطا وثيقَّا معنويًا وماديًا. للتلك يجب أن تكون أدوات إنشاء التوقيع من رموز وأرقام متميزة بشكل فريـ ومرتبطة بالشخص صـاحب التوقيع الإكترونـي. وهذا مسانص تعليه المسادة(r r) مـن قانون المعاملات الإكترونية العماني،كما وردت في قانون الأونيسترال النموذجي وفي توجهات الاتحاد الأوروبي.

\section{ب- أن يكون التوقيع كافيا” للتعريف بشخص صاحبه}

ولابد أن يكون التوقيع الإكتروني الموثق قادرًا على التعريف بشخص صساحبه، كما هو التوقيع العـادي يـل على شخص صساحبه كالإمضاء أو الختم أو البصمة وهذا لايعني أن يتكون من اسم الموقع أو يشمل هبل يكفي أن يركز على تحديد أو التحقق من شخصية الموقع على الرسـائل الإكترونية ويتم هذا التحقق مـن خـلال الرجوع إلى لى مصادر أخرى للمعلومات'، مثل الجهات التي تقوم بإصدار شـهادات التوثيق المعتمدة لمن يريد إن شاء توقيع إلكتروني، فمن خلال هذه الجهات التي يتم الرجوع إليها للتأكد من شخصية الذي يستخدم التوقيع الإكتروني.

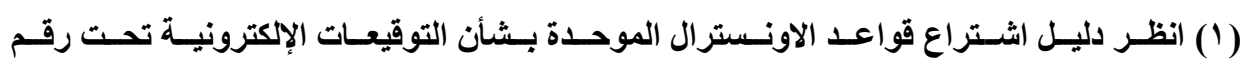

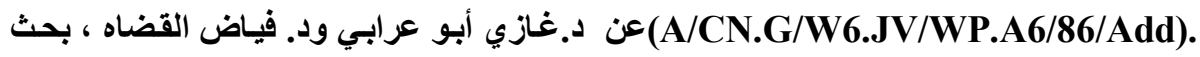

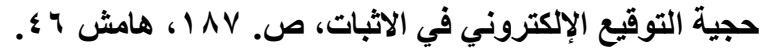


ج - أن يتم إنشاء التوقيع الإلكتروني بوسائل خاصة بالشخص وتحت سيطرته ويقصد بذلك وجوب خضوع أدوات التوقيع الإكترونسي الموثق بأي صورة من

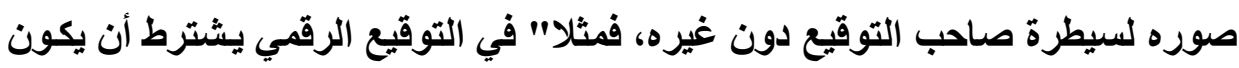

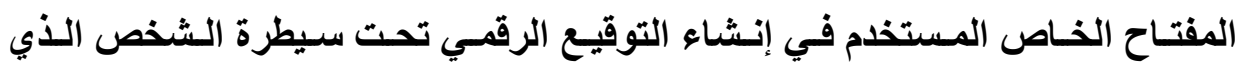
يستخدمه، والذي يقع عليه واجب رعايـة زوج المفاتيح التي يستخدمها، والسيطرة التهاء عليه بعد من شرها والإفصاح عنها لأحد غيره. وقد نصت القو اعد الموحدة الخاصة

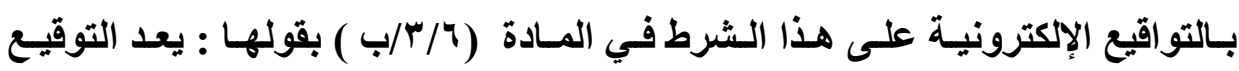
الإكتروني موثقًَا إذا كانت الوسيلة المستخدمة لإنشاء التوقيع الإلكتروني خاضسعة في وقت التوقيع لسيطرة الموقع دون أي شخص آخر. أن يرتبط التوقيع بالسجل الذي يتعلق به بصورة لاتسمح بإجراء تعديل على تونى القيد بعد توقيعه دون إحداث تغيير في التوقيع.(') يشترط في التوقيع الإكتروني أن يكون مرتبطا بالسجل الذي يتطلق بـه بصورة

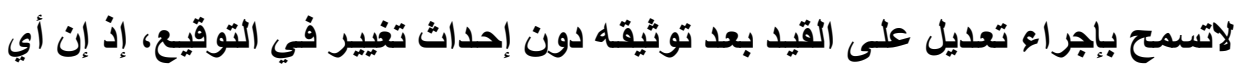
تعديل في القيد بعد توثيقه يجب أن يحدث تعديلا بالتوقيع الإكترونسي والعكس صحيح.

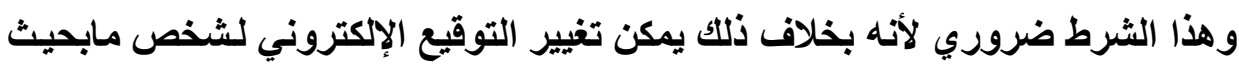

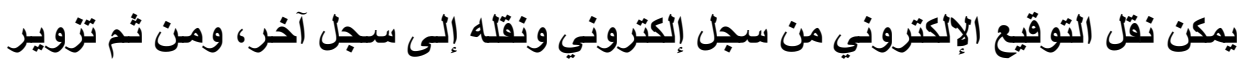
التوقيع الإلكتروني و السجل الإكتروني. 


\section{الفرع الثاني \\ الشروط الشكية المطلوبة في التوقيع الإلكتزوني \\ وتتمثل هذه الشروط بمايأتي:}

ا أن يتم التوقيع خلال سريان شهادة التوثيق.

يجب أن يتم التوقيع خـلال مـدة سـريان شـهادة توثيق معتمـدة ومطابقـة لرمـز

التوقيع الإكترونسي مـع رمز التعريف المبين في تلك الشهادة حتى يستطيع التوقيع

الإكترونـي الموثق مـن القيـام بمهمتهـه بتوثيق سجل إلكترونـي أو جزء منـهـ ويقصد

بشهادة التوثيق الثهادة التي تصدر عن جهة مختصة مرخصة أو معتمدة لإثبات نسبة توقيع إلكتروني إلى شخص معين استنادًا إلى إجراعات توثيق معتمد، وهذا مانصت عليه المادة ( إع ) من قانون المعاملات الإكترونية العماني .

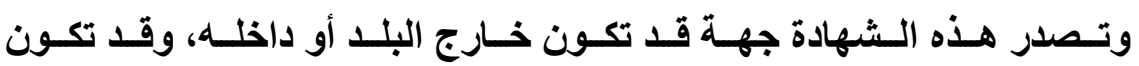

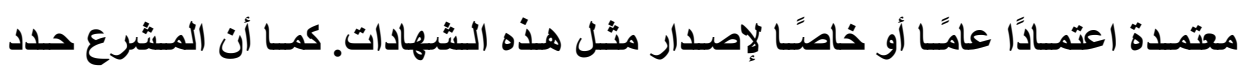
البيانـات التـي يجب أن تحتويهـا شـهادة التوثيتق وكيفيـة اسـتعمالها وضـوابط ذلـك، فقد نصت الماده رقم (بr) من قانون المعاملات الإكترونية العماني على أنه "يجب أن تبين الشهادة :

أ. هوية مقدم خدمات التصديق.

ب. أن الموقع يسيطر في الوقت المعني على أداة إنشاء التوقيع المشـار إليه في الشهادة.

ج. أن أداة إنشاء التوقيع كانت صحيحة وصالحة في تاريخ إصدار الشهادة . 
د. أية قيود على النطاق أو القيمة التي يجوز استخدام الشهادة فيها . هـ ـأية قيود على نطاق أو مدى المسئولية التي يقبلها مقدم خدمات التصديق تجاه

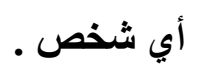

و. أية بيانات أخرى تحددها السلطة المختصة."

نخلص مما تقدم إلى أن شـهادة التوثيق هي عبارة عن سجل إلكترونسي صسادر عن سلطة محايدة تحتوي بيانات مهمة عن الشخص وخاصـة مفتاحه العام، وتستخدم التصديق التوقيع الإكترونسي والمعاملات التي تجري عبر الشبكات المفتوحة، فهذه الثهادة يمكن الاطلاع عليها، ومن خلال المفتاح العام يستطيع أي شخص يريـا التعاقد مـع آخر إرسـال رسـالة إلكترونيـة مسشفرة بالمفتـاح العـام الموجـود في الشهادة، ولا يستطيع أن يفك التثفير إلا من لايه المفتاح الخاص الذي يحتفظ به سرًا.

r r r أن تكون شهادة التوثيق هعتمدة. وكما أشرنا سابقًا فإن شهادة التوثيق تكون معتمدة في الحالات الآتية: أ- إذا كانت صادرة عن جهة هرخصة أو هعتمدة.

وهذه الجهة التي تصدر الشهادة الإلكترونية للتوثيق مرخصة ومعتمدة من قبل الجهات المختصة في سلطنة عمان. وهذه الجهة حددها المشرع العمـاني وسماها مقدم خدمات التصديق و أوجب ان يكون حاصـلا على ترخيص بـللك من السلطة المختصة، وفرض عليـه التزامـات نـصت عليهـا المـاده (ع ب) مـن قـانون المعـاملات الإكترونيـة

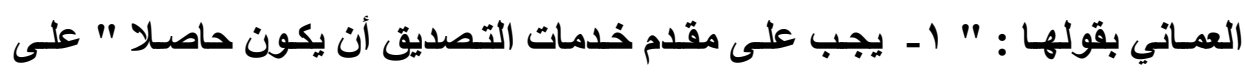
ترخيص بذلك من السلطة المختصة ويلتزم بمايأتي: 
أ. أن يتصرف وفقاً للبيانات التي يقدمها فيما يتعلق بممارساته .

ب. أن يتحقق من دقة واكتمال كل البيانـات الجوهريـة التي تضمنتها الشهادة أثناء

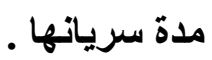

ج. أن يوفر وسائل يكون من الممكن الوصول إليهاوتمكين الطرف الأي يعتمد على خدماتـهـ مـن التأكد ممـايلي: ا ـ هويـة مقـدم خدمات التصديق. ؟ـ أن الشخص المعينة هويته في الشهادة لايسه السيطرة في الوقت المعني على أداة التوقيع المششار إليها في الشهادة.r الطريقـة المستخدمة في تعيسين هويـة الموقع. r- وجود أية قيود على الغرض أو القيمة التي يجوز أن تستخدم أداة التوقيع أو الشهادة من أجلها.بــ صحة أداة التوقيع وعدم تعرضهـا لمـا يثير الشبهة. ـ - الوسيلة المناسبة للإبلاغ عن الإلغاء.

د. أن يـوفر للموقع وسـيلة تمكنهـه من الإبـلاغ في حالـة تعرض أداة إنشاء التوقيع للإخلال، وأن يضمن توفير خدمة لإلغـاء التوقيع يمكن استخدامها في الوقت

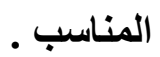
هـ ـ أن يستخدم في أداء خدماتـه نظمـاً و إجراعات ومـوارد بشرية جديرة بالثقة

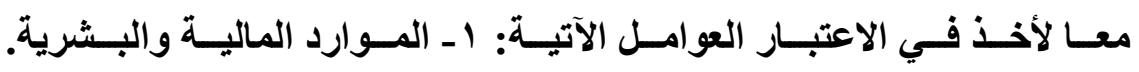
r ـ أجهزة وبـرامج أنظمـة حاسـب آلـي موثـوق بهـا. بـ إجـراعات الشهادات وطلبـات الحصول على الشهادات والاحتفـاظ بالسجلات ـ ـ ـ تـوفير المعلومـات الخاصة بـالموقعين المعرّفين في الشهادات وتوفير المعلومـات للأطراف الذين يحتمل أن يعتمـدوا على خدمات التصديق. هـ انتظـام ومدى تدقيق الحسابات بواسطة جهة مستقلة. 
ب- إذا كانت صادرة عن جهة هرخصة هن سلطة هذتصة في دولـة أخـرى و هعـترف

وهكذا نجد أن القـانون العماني يعترف بشهادات التوثيق الصادرة من الدول

الأخرى، شريطة أن تكون الجهة التي أصدرتها حاصلة على ترخيص من السلطات المختصة بمنح مثل تلك التراخيص في تلك الاول ومعترف بها في سلطنة عمان ـوهنا كالعديد من الشركات التي تصدر شهادات التوثيق أشهر ها(Versign) ـ ج- إذا كانت صادرة عن دائرة حكوهيية أو هؤسسة أو هيئة هفوضة قانونياً بذلك. وهكذا نجد أن القـانون يجيز للاوائر والمؤسسات والهيئات الحكوميـة إصدار شهادات توثيق إذا كاتت مفوضة بذلك خطيا بموجب أحكام القانون ومخولة بإصدار مثل هذه الثهادات.

\section{د- إذا كانت صادرة عن جهة وافق أطراف المعاهلة على اعتـهادها.}

يستطيع أطراف أي معاملـة إلكترونيـة اعتمـاد شـهادة التوثيتق الـصادرة عن أية جهة وافقوا على اعتمادهـا داخل سـلطنة عمـان أو خارجـه، وهذا مـا أكدتها لمـاده رقم (r \&) من نفس القانون والتي ساوث بين الشهادة الصادره من السلطنة والشهادة الــصادرة فـي الخارج،ولكنـهـه اشـترط اعتـراف الــوزير المخـتص بهــا ـ وفـي هـــا إطـلاق لحريـة الأطـر اف في اختيـار الجهـة التـي يرونهــا مناسبة مـن أجـل إصــار

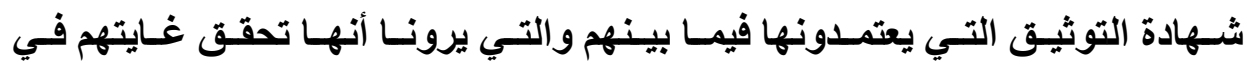
توثيق معساملاتهم الإلكترونيـة، ويطلق على الجهـة التي تصدر شـهـادة التوثيق في 
د/ أحمد عبد الكريم موسى الصرايره

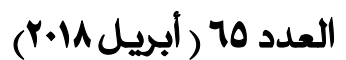

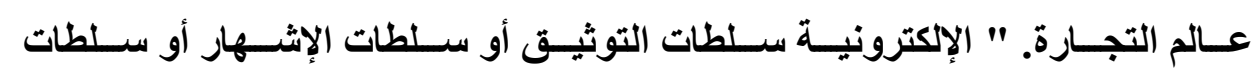
"certification" (التصديق(1)

المطاب الثانسي

\section{نطاق قبـول التوقيـ الإلكتزونسي}

حـد قـانون المعساملات الإكترونيــة المعـاملات العمـــي التــي يقبـل فيهــا

التوقيع الإكتروني وتلك التي لايقبل فيها هذا التوقيع، وكذلك المعاملات التي يتطلب القانون لها شكلا معينًا وإجراءات محددة، إذا سيتناول البحث في الفرع الأول المعاملات التي يقبل فيها التوقيع الاكتروني ثم المعاملات التي لايقبل فيها التوقيع الالكترونسي في الثاني:

\section{الفـــــع الأول}

\section{المعاملات التبي يقبل فيدها التوقيع الإلكترونـي}

بالرجوع إلى قانون المعاملات الإكترونية نجدا أنه نص صراحة على المعاملات التي يقبل فيها التوقيع الإكتروني، وهي المعاملات الآتية-: ا -المعاملات الإلكتزونية الرسمية.

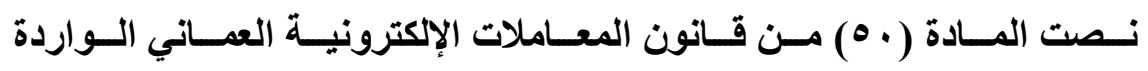
تحت الفــل الثـامن المتعلق باسـتخدام الحكـومي للسجلات والتوقيعـات الإكترونيـة (1) عمر حسن المومني ، التوقيع الإكتروني وقانون التجارة الإلكترونيـة، المرجع السابق ، ص • ؟ـ ك 7 
على أنـه " يجـوز للحكومـة أن تقوم بالمهـام التاليـة باسـتخدام السجلات والتوقيعـات الإكترونية

أ. قبول إيداعأ وتقديمأ و إنشاء أو حفظ مستندات.

ب. إصدار أي إذن أو ترخيص أو قرار أو موافقة. ج. قبول الرسوم أو أية مدفوعات.

د. طرح المناقصات وتسلم العطاءات المتعلقة بالمشتريات الحكومية.

كمـاونـصت المـاده (1 1 ) من القانون نفسه على " يجوز للحكومـة إذا قررت تنفيذ أي من المهام المذكورة في المادة السابقة الكترونيا أن تحدد:

أ. الطريقة والثكل الذي يتم بواسطته إنشاء أو إيداع أو حفظ أو تقديم أو إصدار

$$
\text { تلك السجلات. }
$$

ب. الطريقة والشكل والكيفية والإجراءات التي يتم بها طرح المناقصات وتسلم العطاءات وإن أجاز المشتريات الحكومية.

ج. نـوع التوقيع الإكترونسي المطلوب بمـا في ذلك اشـتراط أن يستخدم المرسل

$$
\text { توقيعاً إلكترونياً محمياً آخر. }
$$

د. الطريقة والشكل الذين يتم بـه مـا تثبيت ذلك التوقيع الإكترونـي على السجل والمعيار الذي يجب أن يستوفيه مقدم خدمات التصديق الذي تقدم إليه السجلات

$$
\text { للإيداع أو الحفظ. }
$$

هـ ـ عمليات وإجراعات الرقابة المناسبة للتحقق من سلامة وأمن وسرية السجلات

$$
\text { الإكترونية أو المدفوعات أو الرسوم. }
$$


و. أيــة مواصــفات أوشـروط أو أحكـام أخـرى لإرســال المـستتـات الورقيـةة،

إذا كـان ذلكـ مطلوبـاً فيمـا يتعلق بالسجلات الإلكترونيـة الخاصـة بالمـدفوعات

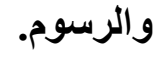

ويتضح من هذين النصين أنهمـا يفتحسان المجـال واسـعًا أمسام الدوائر الحكومية والمؤسسات الرسمية لاستخدام الوسائل الإكترونية في إن أجاز المعاملات المختلفة، والتي تتم عن طريق الورق وتتطلب وقتَّا طويلا، فـالنص ان أجـاز استخدام الوسـائل الإكترونية في المعاملات التي تجريها الدوائر والمؤسسات الرسمية، سواء كان ذلكك يستغرق كل نشاطها أو جزعًا منـه'. وتتأتي أهميـة هذه النصوص في إطـار دعم توجه

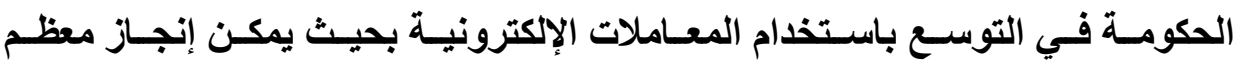

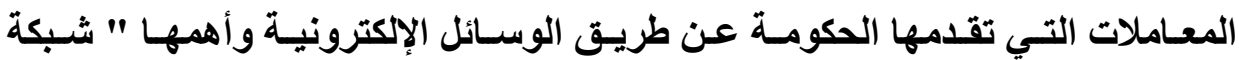

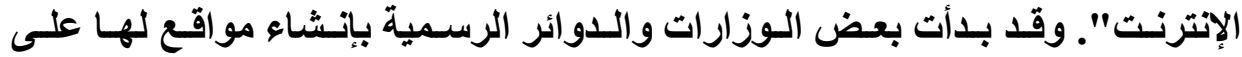
الإنترنت بحيث تستطيع تقديم خدماتها وإنجاز معاملاتها عن طريق هذه الشبكة. ولابد مـن التأكيد على أن المعـاملات التي يمكن إنجازهـا عن طريق الوسـائل الإكترونيـة. يتطلب لصحتها أن يتم استخدام التوقيع الإكتروني المدعوم بشهادة توثيق معتمدة من إحدى جهات الاعتماد حتى تستطيع الائرة الحكومية أو المؤسسة التحقق من شخصية الشخص المتعامل معها، وهذا يفتح المجـال أمسام ظهور الإسنـاد الرسمية الإكترونية التي سيكون لها دور خاص في النظام القانوني للإثبات. 


\section{r - المعاهلات التي يتفق عليها الأطراف.}

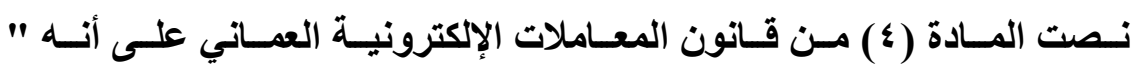

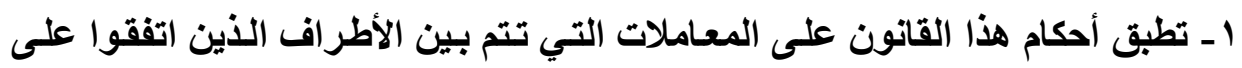

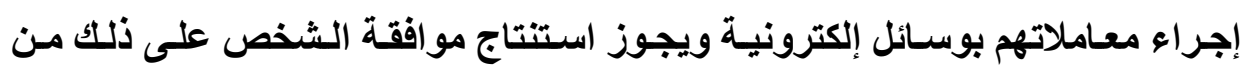

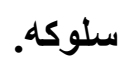

وبالنـسبة للحكومـة، يجـب أن يكسون قبولهـا بالتعامـل الإكترونـي صـريحاً.

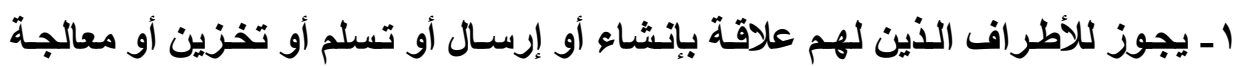

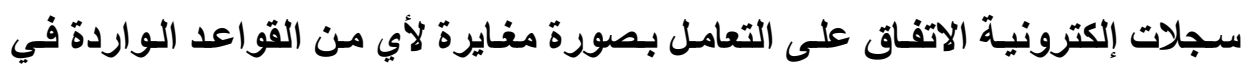

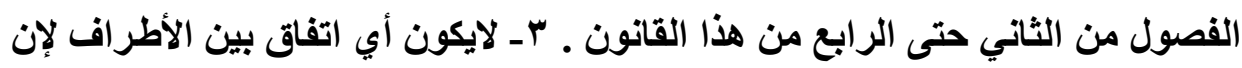

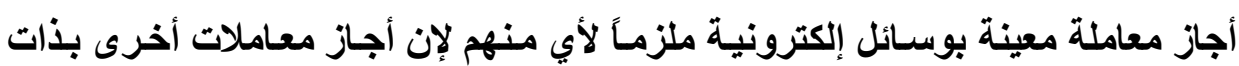

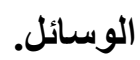

يتضح من هذا النص أن القانون أجساز للأفراد الاتفاق على إجراء معاملاتهم بوسائل إلكترونية مهما كانت هذه المعاملات، وهذا يعني أن التوقيع الإكتروني يكون مقبولا في مثل هذه المعاملات بشرط أن يستوفي جميع الشروط والأوضساع التـي اشترطها القانون لذلك، عندئذ يتمتع هذا التوقيع بالحجية القانونية الكاملة. والمعاملات التي يتفق الأطراف على إجرائها كثيرة ومتنوعة تثثل جميع أنواع المعاملات المدنية والتجارية التي يرغب الأثخاص الطبيعيون و المعنويون إجراءهـا باستخدام الوسـائل

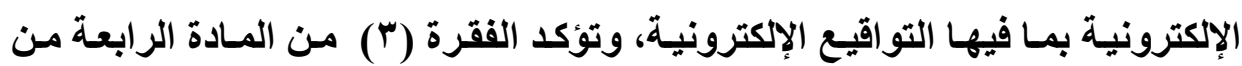

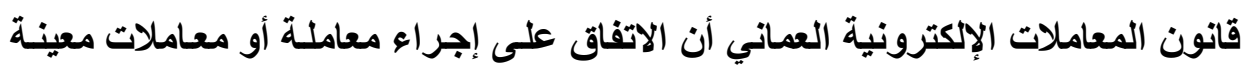

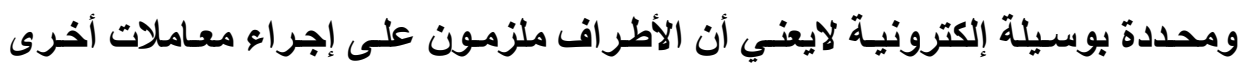

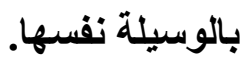




\section{الفـــرع الثاني \\ المعاملات التي لايقبل فيها التوقيع الإلكترونسى}

نصت المادة (با) من قانون المعاملات الإكترونية العماني على أنه " تسرى

أحكام هذا القانون على المعاملات والسجلات والتوقيعات الإكترونية كماتسري على أية

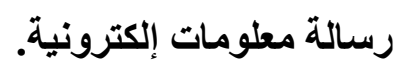

ولايسري هذا القانون على مايلي:

1 ـ المعـاملات والأمسور المتعلقـة بقـانون الأحسوال الثخـصية كـالزواج والطـلاق

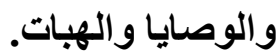

r - إجراءات المحاكم والإعلانات القضائية والإعلانات بالحضور و أوامر التفتيش

وأو امر القبض والأحكام القضائية.

rـ أي مستتد يتطلب القانون توثيقه بواسطة الكاتب بالعدل.

نخلص من ذلك إلى أن العقود و الوثثائق والمستندات التي تنظم وفقًا لتشريعات

خاصة ويلزم لها شكل معين وإجراءات محددة جاءت على سبيل المثال لا الحصر. أمسا

الأوراق المالية فلا يجوز إصدارها بوسـائل إلكترونية بل يتم ذلكك بـالطرق المعتمدة

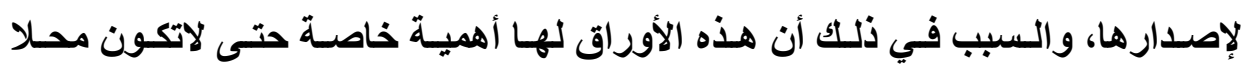

للتلاعب و التزوير، لذلك يتطلب القانون لها إجراءات معينة ـوفي هذا الصدد نلاحظ أن قانون المعاملات الإكترونية العماني قد ترك الباب مفتوحًا للجهات المختصة بإصدار

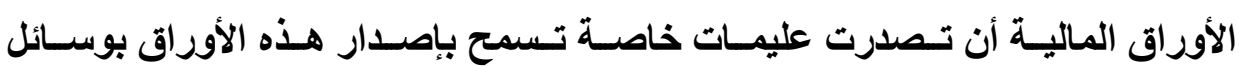

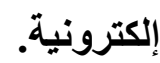




\section{الامطاب الثالث}

\section{الأثــر القانونـــي التوقيع الإلكترونــي في الإثبات}

نصت المـادة (V) مـن قانون المعـاملات الإكترونية العمـاني على أنـه " تتـتج الرسالة الإكترونية أثرها القانوني وتعتبر صحيحة وقابلة للتنفيذ شـأنها في ذلك شـأن الوثيقة المكتوبة إذا روعيت في إنشائها واعتمادها الشروط المنصوص عليها في هذا القانون واللوائح والقرارات الصادرة تنفي إذا لأحكامه."

يتضح من خلال هذا النص أنسه إذا تم توثيق التوقيع الإلكترونسي بصورة كاملة واستوفى جميع المتطلبـات التي يفرضـها القـانون، فأنـه يرتب الآثار القانونية إذا تها المترتبة على التوقيع الخطي، لإذا سيتناول البحث الآثار القانونية التي تترتب على التوقيع الإكتروني الموثق توثيقا صحيحا في فرعين سيتناول (ألفرع الأول) الأثر الأول وهو إلزام التوقيع لـصاحبه ـأمسا الاثر الثاني وهو صـلاحية التوقيع الإكترونـي في الإي الإثبات في (ألفرع الثاني)على النحو التالي:

\section{الفرع الأول}

\section{إلــــزام التوقيع الإلكتزونـي لصاحبه}

أن مجرد وضع التوقيع على أي ورقة أوسجل أو مستند سواء كان هذا التوقيع إمضاء أم ختمًا أم بصمة يجعل صاحبه ملزمًا بما ورد في الورقة أوالسجل أو المستتد مـن حقوق والتزامـات وهذا مـا أكدتـهـ المسادة(ه l) مـن قـانون الإثبـات في المعـاملات

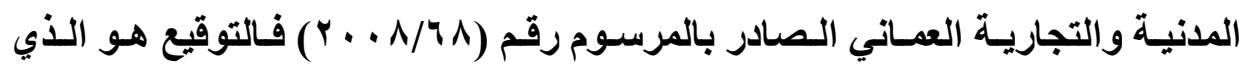


يعطي القيمة القانونيـة للكتابة المدونـة على الورقة أو السند ' وكذلك الأمر بالنسبة

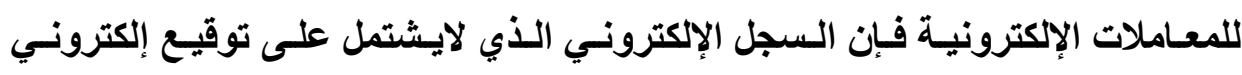
لاتكون له أي حجة أو قيمة قانونية في الإثبات.

وهذا يتطبق على التوقيع الإكترونسي إذ إن وجـود التوقيع الإكترونسي على سلى

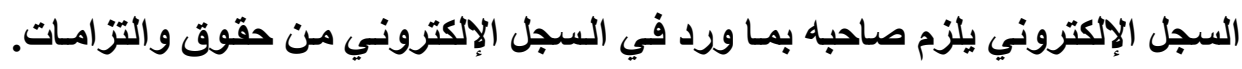

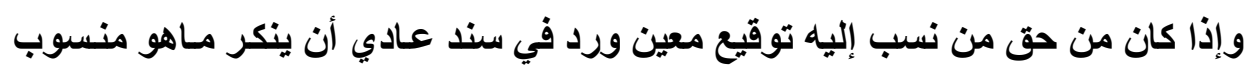
إليه من توقيع أو يطعن بتزوير ذلك التوقيع إن كان مصدقا عليه وهذا منا مـا أكدته المـاده

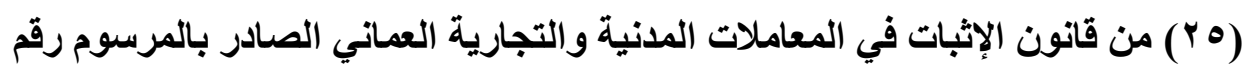

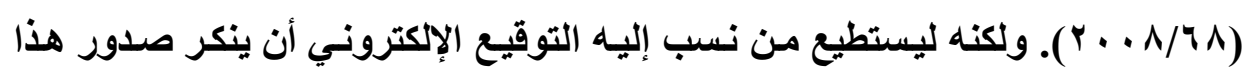

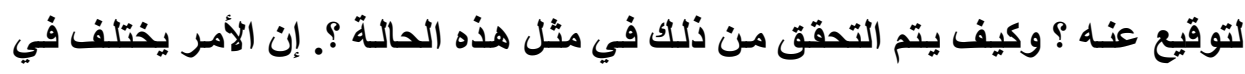

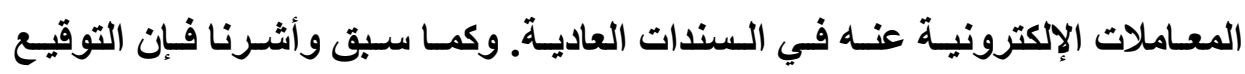

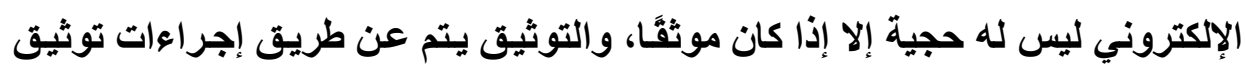

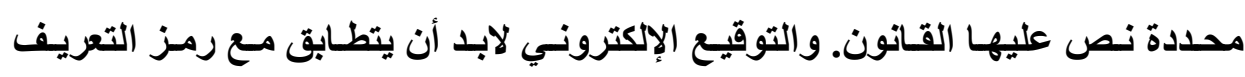

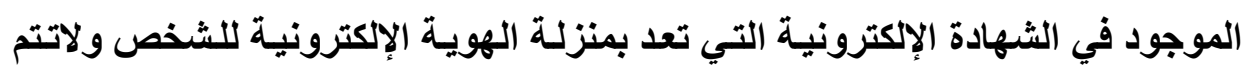

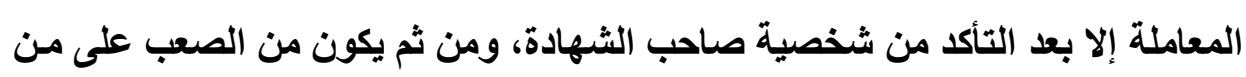

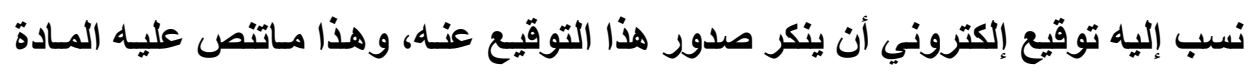

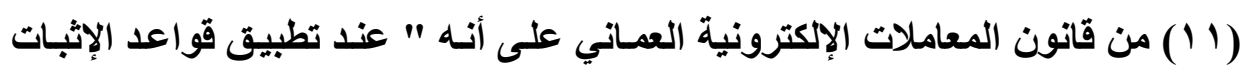

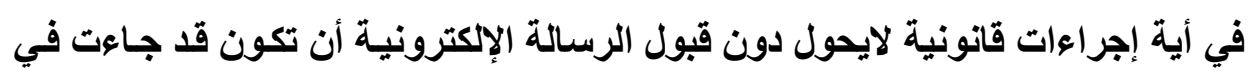


غير شكلها الأصلي، إذا كاتت الرسالة أفضل دليل يتوقع بلرجة مقبولة أن يحصل عليه الشخص الأي يقدمه. وتكون لهذه الرسالة حجية في الإثبات، مع مراعاة الآتي: أ. مدى إمكانية الاعتماد على الطريقة التي تم بها تنفيذ واحدة أو أكثر من عمليـات التنفيذ أو الإدخال أو الإنشاء أو المعالجة أو التخزين أو التقديم أو الإرسال. ب. مـدى إمكانيـة الاعتمـاد علـى الطريقـة التـي تمــت بهـا المحافظـة على سـلامة المعلومات. ج. مدى إمكانية الاعتماد على مصدر المعلومات إذا كان معروفًا. د. مدى إمكانية الاعتماد على الطريقة التي تم بها التحقق من هوية المنشئ إذا كانت ذات صلة. هـ ـ أي عامل آخر ذو صلة. مالم يثبت العكس، يفترض أن التوقيع الإكترونسي محمي إذا استوفي الشروط

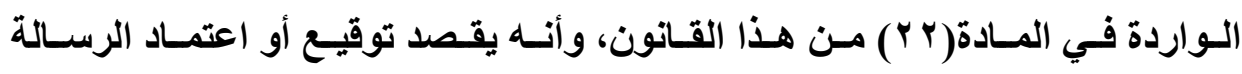
الإكترونية التي وضع عليها أو اقترن بها ولم يتغير منذ إنشائه، وأن هذا التوقيع جدير بالاعتماد عليه." كما نصت المادة (Y Y ) من قانون المعاملات الإكترونية العماني على ملى أنه " يعتبر التوقيع الإكتروني محمي أو جديرا بأن يعتمد عليه إذا تحقق الآتي: أ. كانت أداة إنشاء التوقيع في سياق استخدامها مقصورة على الموقع دون غيره. ب. كاتت أداة إنشاء التوقيع في وقت التوقيع، تحت سيطرة الموقع دون غيره. ج. كان ممكناً كشف أي تغيير للتوقيع الإكتروني يحدث بعد وقت التوقيع. 
د. كـان ممكناكثف أي تغيير في المعلومسات المرتبطة بالتوقيع يحدث بعد وقت

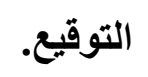

ومع ذلك يجوز لكل ذي شأن أن يثبت بأية طريقة أن التوقيع الإكترونس جدير

بأن يعتمد عليه أو أنه ليس كذلك."

ويتضح من هذين النصين أن القانون وضع قرينة بسيطة قابلة لإثبات العكس مفادها أن التوقيع الإكتروني الموثق لـه حجية في قانون المعاملات الإكترونية بأنها صادر عن الثخص المنسوب إليه دون غيره، ومن ثم يكون ملزمًا بـه، ويتحمل مـافي

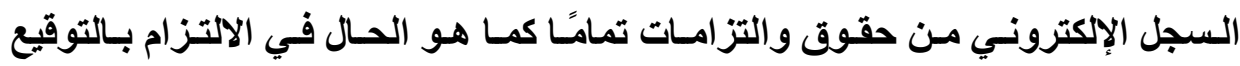

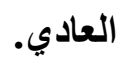

\section{الفرع الثاني}

\section{صلاحيـة التوقيــــع الإلكتزونسي في الإثبات.}

نـصت المسادة (ب ا ) مـن قـانون المعساملات الإكترونيـة العمساني علـى أنسه "

1ـ يجوز إبرام عقد بين نظام معلومـات آلي مملوك لشخص طبيعي أو معنوي وبين شخص طبيعي أو معنوي إذا كان الأخير يعلم أو كان ينبغي عليه أن يعلم أن ذلك النظام

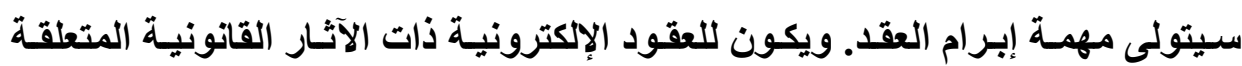
بالعقود التي تبرم بالأساليب العادية من حيث الإثبات والصحة والقابلية للتنفيذ وغير ذللك من الأحكام".

يتضح من خلال النص بالفقرة الثانيه أن قانون المعاملات الإكترونية قد أعطى التوقيع الإكترونـي الأثر القانوني نفسه الذي منحسه للتوقيع العـادي من حيث إلزامـه 
لصاحبه، فأنه قد أعطاه أيضًا الأثر نفسه فيما يتعلق بصلاحيته في الإثبات وهنا لابد من

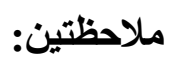

الأولى : أن قانون المعاملات الإكترونية اعتبر التوقيع الإكترونسي صـالحًا للإثبات

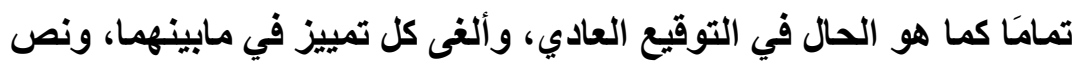
على عدم جواز التمييز ضد التوقيع الإكتروني، وعدام إغفال الأثر القانوني له لا لا أنه ورد بوسيلة إلكترونية. الثانية: أن التوقيع الإكتروني له صلاحية كاملة في الإثبات بحيث لله القدرة على

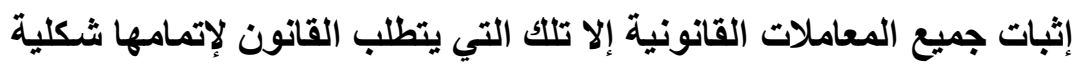

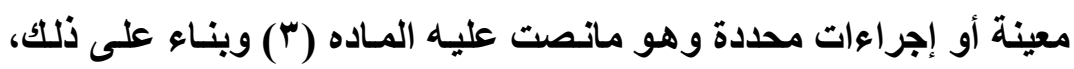
فِان التوقيع الإكترونسي يصلح لإثبات جميع المعاملات التي يتم إجراؤها

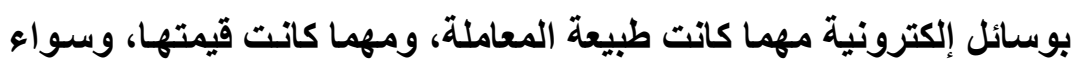

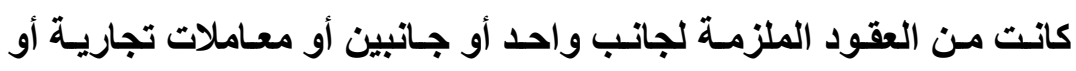

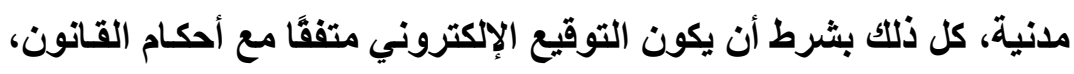

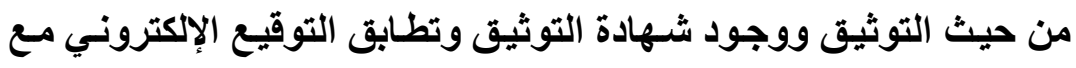

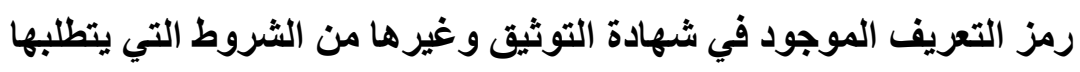
القانون لكي يكون التوقيع الإكتروني صالحًا للإثبات. 


\section{قائمة المراجع}

أولا - الكتب

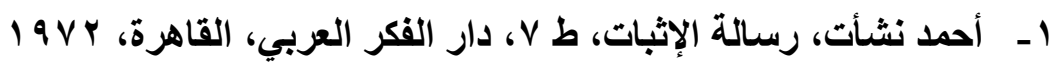
r- - إسـماعيل غـانم، أحكـام الالتزام والإثبات،الجزء الثاني، القـاهرة، مكتبـة عبد الله

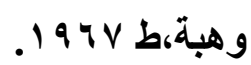

r- أسامة أحمد شوقي المليجي، استخدام مستخرجات التقانات العلمية الحديثة وأثره

$$
\text { على قواعد الإثبات المدني دار النهضة العربية،القاهرة، .... ب. }
$$

ع - حسن عبد الباسط جميعي، إثبات التصرفات القانونية التي يتم إبرامها عن طريق

$$
\begin{aligned}
& \text { الإنترنت، دار النهضة العربية،القاهرة، . . . . . } \\
& \text { هـ - سليمان مرقس: }
\end{aligned}
$$

ـ الوافي في شرح القانون المدني، الجزء الثاني، المجلا الأول، نظرية العقد، الطبعة

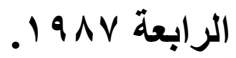

ـ أصول الإثبات وإجراعاتـه في المـواد المدنيـة، ط ع،ج ب ،دون دار ومكان للنشر،

$$
.1914
$$

צ- طوني عيسى ميشال، التنظيم القانوني لشبكة الإنترنت، ط ا، بيروت . . . . . V- محمد المرسي زهرة، أحكام الإثبات في المواد المدنية والتجارية ـ الأدلة المطلقة. دار الكتاب الجامعي ، العين ، دولة الأمارات العربية المتحدة، سنة ؛ ا ـ ؟ . 
^- محمد حسام لطفي، استخدام وسائل الإتصال في التفاوض على العقود و إبرامها،

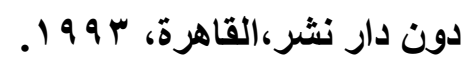

9- مقلح عواد القضاة، البينـات في المواد المدنية والتجاريـة، جمعية عمـال المطابع

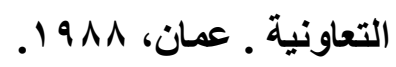

• 1 ـ عمر حسن المـومني، التوقيع الإكترونـي وقـانون التجـارة الإكترونيـة، دار وائل

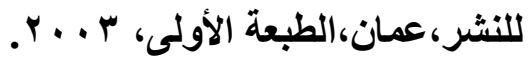

\section{ثانيًا- الدوريات}

1 ا ـ حـازم الصمادي، نطاق مسؤولية المصرف والوسـائل القانونيـة الإكترونيـة في الإثبات، مجلة البنوك في الأردن، مجلد 9 ، ،عدد . 1 ،كانون الأول.

\section{ثالثاً- الرسائل الجاهمية والبحمث}

r ا ـ غازي أبو عرابي ، د.فيـاض القضاه، حجية التوقيع الإكترونـي في الإثبات في

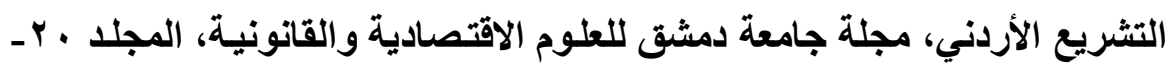

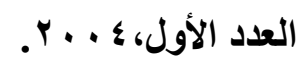

با ـ ـ محمد المرسي زهرة، مدى حجية التوقيع الإكتروني في الإثبات في المواد المدنية والتجارية، مؤتمر الحاسب والقانون ، جامعة الكويت ، الكويت، 9 ، 9 ـ . 